\title{
The influence of the geomorphological and sedimentological settings on the distribution of epibenthic assemblages on a flat topped hill on the over-deepened shelf of the western Weddell Sea (Southern Ocean)
}

\author{
B. Dorschel, J. Gutt, D. Piepenburg, M. Schröder, and J. E. Arndt \\ Alfred-Wegener-Institut Helmholtz-Zentrum für Polar- und Meeresforschung, Bremerhaven, Germany \\ Correspondence to: B. Dorschel (boris.dorschel@awi.de)
}

Received: 21 November 2013 - Published in Biogeosciences Discuss.: 23 January 2014

Revised: 5 June 2014 - Accepted: 6 June 2014 - Published: 21 July 2014

\begin{abstract}
Epibenthos communities play an important role in the marine ecosystems of the Weddell Sea. Information on the factors controlling their structure and distribution are, however, still rare. In particular, the interactions between environmental factors and biotic assemblages are not fully understood. Nachtigaller Hill, a newly discovered seabed structure on the over-deepened shelf of the northwest Weddell Sea (Southern Ocean), offers a unique site to study these interactions in a high-latitude Antarctic setting. Based on highresolution bathymetry and georeferenced biological data, the effect of the terrain and related environmental parameters on the epibenthos was assessed. At Nachtigaller Hill, both geomorphological and biological data showed complex distribution patterns, reflecting local processes such as iceberg scouring and locally amplified bottom currents. This variability was also generally reflected in the variable epibenthos distribution patterns although statistical analyses did not show strong correlations between the selected environmental parameters and species abundances. By analysing the interactions between environmental and biological patterns, this study provides crucial information towards a better understanding of the factors and processes that drive epibenthos communities on the shelves of the Weddell Sea and probably also on other Antarctic shelves.
\end{abstract}

\section{Introduction}

Epibenthos distribution patterns often correlate with environmental parameters such as e.g. substrate, food supply and temperature. Some of these parameters are influenced by the morphology of the terrain (geomorphology) including relevant ecological drivers (Bowden et al., 2011; Dorschel et al., 2007; e.g. Genin et al., 1986; Gutt, 2000; Wienberg et al., 2013; Williams and Leach, 1999). Bottom currents for example are often enhanced at hill flanks and around obstacles (Dorschel et al., 2007; Guo et al., 2000). These enhanced bottom currents can increase the food supply for filter feeders and remove fine sediments causing winnowing. This has already been demonstrated for a range of hills, mounds and seamounts (e.g. Dorschel et al., 2007; Genin, 2004; Genin et al., 1986; Piepenburg and Müller, 2004). Remaining coarse lag sediments or exhumed consolidated sediments can provide substrates suitable for sessile life forms. On the other hand, less dynamic and sheltered environments provide habitats preferred by dominantly deposit-feeding benthic organisms.

In the marine ecosystems of the Weddell Sea shelves, epibenthos communities play an important role (Dayton, 1990; Gutt et al., 2011; Starmans et al., 1999). Biological and environmental data regarding the environmental factors controlling their distribution patterns on the scale of the entire Antarctic shelf are, however, still rare (Post et al., 2011; Raguá-Gil et al., 2004). Furthermore, it cannot be ruled out that biological interactions rather than physical factors are the dominant drivers (Gutt, 2000). Towards a comprehensive understanding of these ecosystems, information on the interaction, responses and feedback mechanisms between seabed communities and environmental conditions are crucial. This is especially true since it is known that some important 
physical drivers, such as ice cover, current regime and sediment characteristics, potentially shape these high-latitude Antarctic marine communities (Cummings et al., 2010).

During cruise ANT-XXIX/3 of the German RV Polarstern, we coincidentally discovered a previously unknown hill on the shelf of the northwest Weddell Sea that we named Nachtigaller Hill (also known as Nachtigaller Shoal, Fig. 1). It is located to the east off the Antarctic Peninsula in the Erebus and Terror Gulf in the extension of the Antarctic Sound (Fig. 1). Climatically, the study site experiences full highlatitude Antarctic conditions typical for the Weddell Sea with low precipitation (Sugden, 1982) and seasonal to perennial ice cover. The general oceanography at the site is characterised by the influence of the western extent of the Weddell Gyre (e.g. Orsi et al., 1993). Detailed information on the oceanic conditions of the continental shelf of the northwest Weddell Sea are, however, sparse (Camerlenghi et al., 2001).

The unique and obvious shape and pronounced geomorphology of Nachtigaller Hill makes it a key site for studying habitat and benthic community distribution patterns across a range of environmental settings in full, high-latitude Antarctic conditions. At submarine hills with distinct geomorphologies, like Nachtigaller Hill, the biological patterns potentially reflect the environmental settings more clearly than in areas with less pronounced geomorphologies. Thus, this study provides valuable information towards a better understanding of ecosystem functioning and bioenvironmental interactions in the western Weddell Sea and other areas on the Antarctic shelf.

In a cross-disciplinary approach, we

1. describe, classify and interpret the geomorphology of Nachtigaller Hill based on bathymetric data,

2. analyse (a) the sedimentary settings and (b) epibenthos communities based on seabed imagery and, using a geographical information system (GIS),

3. assess and explain epibenthos distribution patterns in relation to environmental factors by correlating environmental with biological observations.

The descriptive part of this study contributes to the general knowledge about an, in some respects, "white spot" on geomorphological and biogeographical maps.

Southwest of our research area, Gutt et al. (2011) have surveyed the Larsen A and B areas (Fig. 1) in 1995 and 2002, to study the response of the benthos to the collapse of the Larsen ice shelves. As reference sites, they chose locations in the vicinity of Nachtigaller Hill (east of Ross Island and south of Joinville Island), where the seabed is massively disturbed by grounding icebergs. Both phenomena, disintegration of ice shelves and iceberg scouring, represent very specific environmental processes, which can a priori not be applied to our study area. Results from Bertolin and Schloss (2009) and Peck et al. (2010), however, showed that in the
Larsen bights and in the former ice shelf areas, which are relatively close to the Nachtigaller Hill, primary production can be high. Furthermore, Gutt et al. (2012) demonstrated that sponge communities, as they are known from the southeast Weddell Sea (see also Sañe et al., 2013), and other "normal" shelf areas in the Southern Ocean (Gutt et al., 2013a) can also occur in this part of the Weddell Sea. Because of the extremely slow growth of large glass sponges and also some demosponges (Dayton, 1989; Dayton et al., 2013), such communities, if mainly composed of large specimens, are indicators of long-term environmental stability. However, it has been shown that populations of ascidians and ophiuroids (Gutt et al., 2013a), young hexactinellid sponges (Fillinger et al., 2013; Gutt et al., 2012) as well as generally fast-growing demosponges known for their highly dynamic performance (Gutt et al., 2012), including reproduction, recruitment, growth and mortality, can also occur in the same area. Since we know that almost everywhere on the "normal" Antarctic shelf, albeit with different proportions, two community supra-types (those dominated by epifaunal suspension feeders and those dominated by infaunal or vagrant deposit feeders) coexist, we can assume that this can also be applied to the area of this study. The typical high-Antarctic suspension-feeder communities that are rich in biomass and diversity occur in regions, such as the southeast Weddell Sea, where a relatively strong coastal current flows along a less structured coastline over a relatively narrow shelf or where certain geomorphological features (Gutt, 2007; Lavaleye et al., 2005) enhance the advective transport of food for benthic filter feeders, mainly in the form of phytodetritus. Since the northwest Weddell Sea shelf is relatively broad, we hypothesise that suspension-feeder communities are not particularly abundant and rich in the surroundings of the Nachtigaller Hill. On the other hand, the presence of some typical elements of high-Antarctic epibenthic communities in the wider study area provides evidence that the benthos of the west Weddell Sea generally resemble that of the east Weddell Sea with a certain proportion of suspension feeders. In this regard, both Weddell Sea regions are clearly different from the area west of the Antarctic Peninsula, where the environmental setting is characterised by a much more complex coastline, different water masses, and less sea ice (Smith et al., 2006). There, the benthos is generally a food-bank system, where deposited phytodetritus serves as the major energy source, mainly for deposit feeders such as polychaetes and vagrant holothurians (Sumida et al., 2008). A rare if not unique characteristic of our study site is, however, the shape of the Nachtigaller Hill, with a complex intermediateto small-scale geomorphological terrain heterogeneity.

\section{Material and methods}

All data sets used in this study were collected during cruise ANT-XXIX/3 of the German RV Polarstern in February 


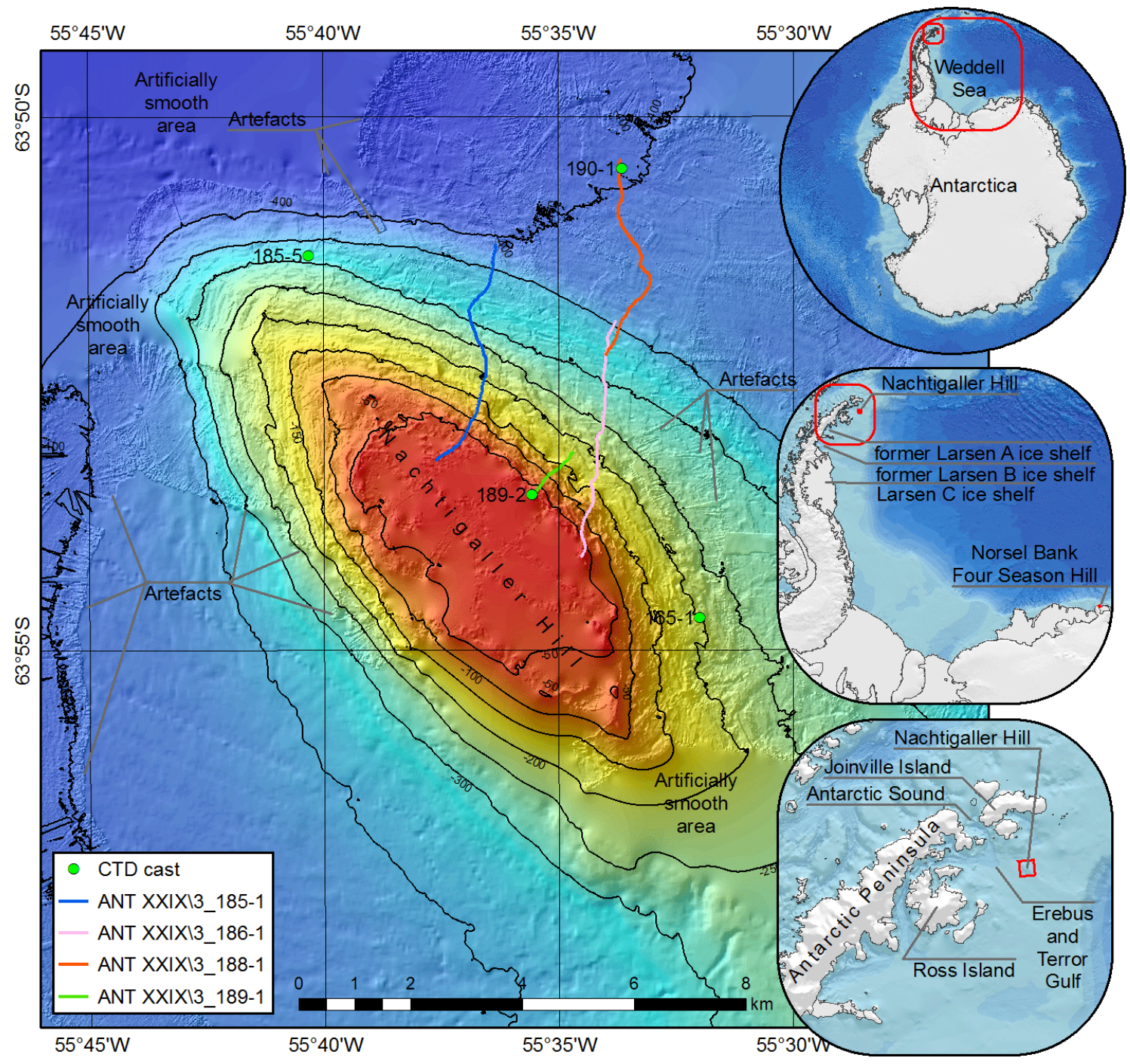

Figure 1. Overview of the research area in the northwest Weddell Sea in the Erebus and Terror Gulf on the over-deepened shelf east off the Antarctic Peninsula. Smooth areas and steps at the sides of the multibeam coverage are artefacts generated by the integration of different bathymetric data sets. The coloured lines represent transects recorded with the Ocean Floor Observation System (OFOS). CTD = conductivity, temperature and depth.

2013 (Gutt, 2013). The data sets include high-resolution multibeam bathymetry data, seabed imagery and hydrographic water-column data. The new data sets span across a depth range from 17 to $460 \mathrm{~m}$ water depth (wd).

\subsection{Hydro-acoustic data}

On Nachtigaller Hill, an area of $120 \mathrm{~km}^{2}$ was mapped during the survey. Due to the shallow water depth above the plateau and the prevailing ice conditions, a full coverage was not achieved. Nevertheless, several survey tracks crossed the hill lengthwise and across (Fig. 2), thus providing sufficient data coverage for characterising also its shallowest parts. While the west, northeast and southeast slopes of the hill were fully mapped, its southwest sector was blocked by icebergs and could not be surveyed (Fig. 2).

\subsubsection{Data acquisition}

The bathymetric data were acquired with an Atlas Hydrosweep DS3 deep-water multibeam echosounder operated in "equal footprint" mode with 313 hard beams and a maximum of 920 soft beams. In the depth range of the study area, the horizontal position accuracy was $2-5 \mathrm{~m}$. The vertical accuracy of the Atlas Hydrosweep DS3 was better than $0.2 \%$ of the water depth.

During post-processing with the hydrographic software package Caris Hips \& Sips ${ }^{\circledR}$ 8.0, the multibeam data were cleaned for artefacts related to erroneous calibration values, 

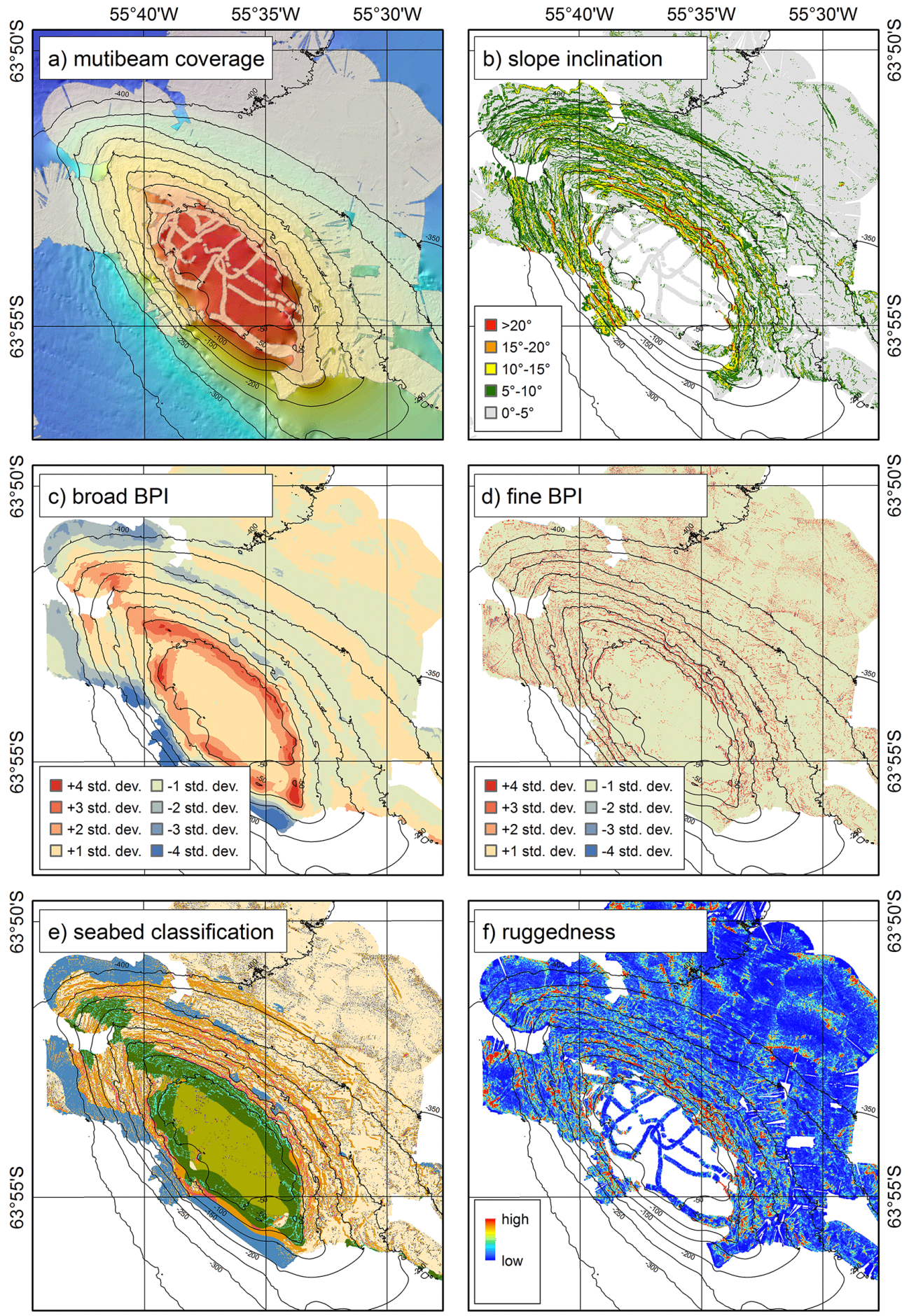

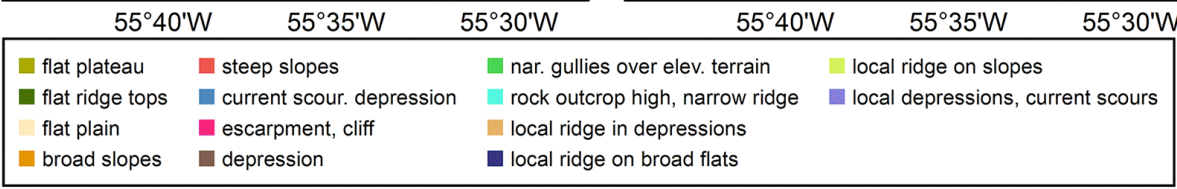

Figure 2. Bathymetry-derived parameters used for seabed classification. (a) Shaded area indicates the extent of the multibeam coverage recorded during cruise ANT XXIX $\backslash 3$ of the RV Polarstern. (b) Slope inclination in degree (first derivate of the bathymetry). (c) and (d) Focal statistic raster (the basis for the seabed classification) (e) BTM seabed classification (f) Ruggedness - the amount of variability (or bumpiness) of the seabed. Being very sensitive to outer beam variability, the ruggedness shows in addition to real data also artificially high values in the flat area off the hill. BIP = benthic position index. 
spurious soundings, vessel motion, navigational jumps and sound velocity refractions. Sound velocity corrections were applied based on sound velocity profiles calculated from conductivity temperature and depth (CTD) data using the approach by Chen and Millero (1977). In addition, the preprocessed data were imported in the editing and visualisation software package QPS Fledermaus ${ }^{\circledR}$ for area-based editing.

\subsubsection{Digital terrain model generation}

From the cleaned swath bathymetry data sets, a digital terrain model (DTM) was created (Fig. 1). Gaps in the multibeam coverage of Nachtigaller Hill were filled and interpolated on the basis of the International Bathymetric Chart of the Southern Ocean (IBCSO) grid (Arndt et al., 2013) by applying "remove-and-restore" techniques (Arndt et al., 2013; Jakobsson et al., 2000, 2008, 2012). Horizontal resolutions were $10 \mathrm{~m}$ for areas with multibeam coverage recorded during our cruise, $500 \mathrm{~m}$ for areas previously mapped and $2000 \mathrm{~m}$ for areas where the bathymetry was derived from the General Bathymetric Chart of the Ocean (GEBCO) and satellite altimetry. For a better consistency of the DTM and to minimise artefacts arising from the use of various data sources, an integration (bending) algorithm (Arndt et al., 2013) was applied. The final DTM was projected to UTM Zone $21 \mathrm{~S}$ with a datum of WGS1984. For all subsequent analyses, raster data sets were derived from this DTM.

\subsection{Geostatistical analyses}

Geostatistical analyses were performed with $\operatorname{ArcGIS}^{\circledR}$ including the toolbox extensions Benthic Terrain Modeller (BTM) (Wright et al., 2005) and the LandSerf software (Wood, 2009a). In both software packages, raster analyses were performed at a number of scales following a trial-anderror approach to find the best representation of the different geomorphological features encountered at the Nachtigaller Hill. For consistency, these analyses were limited to the areas with high-resolution $(10 \mathrm{~m})$ multibeam coverage and the shallow parts of the hill (Fig. 1). To further reduce the influence of potential artefacts from outer beams of the multibeam sonar swath, the outer $50 \mathrm{~m}$ of the multibeam coverage and hill area were ignored in all geostatistical analyses

For visual inspections, and for a more natural representation of the bathymetric data, hillshade images were calculated in ArcGIS ${ }^{\circledR}$. Hillshade images provide an illuminated, pseudo-3-D impression that allows for the identification of small morphological structures that were otherwise unrecognisable in the bathymetry data. In addition, slope (the first derivative of the topography) and ruggedness (a second derivative of the topography) were calculated as topographic terrain descriptors. Slope calculations were performed in ArcGIS ${ }^{\circledR}$ applying the equation described in Burrough and McDonnell (1998). Ruggedness was calculated with the LandSerf software (Wood, 2009a) from a bivari- ate quadratic approximated terrain surface (Wood, 2009b) and was measure for the roughness or "bumpiness" of the seabed (Wilson et al., 2007). For more advanced geostatistical analyses, a focal statistic approach was applied. Both broad-scale and fine-scale bathymetric position index (BPI) grids were calculated using the BTM extension version 3.0 (beta) for ArcGIS 10.1 (Wright et al., 2005). The BPI represents a marine equivalent of the topographic position index commonly used in terrestrial landscape studies (Lundblad et al., 2006; Weiss, 2001) and is a second-order derivative of the bathymetry (Guinan et al., 2009). It calculates the depth differences between each bathymetric raster cell and the average depth of a surrounding reference area (in this study an annulus-shaped area). Consequently, cells with positive BPI values represent parts of elevated features or convex seabed, while cells with negative BPI values belong to depressions or concave seabed. BPI raster were used for geomorphological analyses and for a seabed classification with the BTM (Wright et al., 2005). The BTM comprises a set of algorithms designed for seabed classifications solely on the basis of bathymetric data and bathymetry derivatives (Erdey-Heydorn, 2008; Lundblad et al., 2006; Weiss, 2001; Wright et al., 2005). The BPI rasters formed the backbone of the classification. For the BTM, broad-scale (fine-scale) BPI rasters were computed with an inner radius of $1000 \mathrm{~m}(30 \mathrm{~m})$ and an outer radius of $1500 \mathrm{~m}(50 \mathrm{~m})$. With these parameters, the overall shape of the hill, its plateau, slopes, terraces and the background seabed, were well captured. The fine BPI raster highlighted local feature such as iceberg scours and escarpments. To avoid the influence of spatial autocorrelation in the broad- and fine-scale BPIs, the BPIs were standardised relative to one standard deviation each (Wright et al., 2005). The BTM furthermore requires a classification table to define a classification scheme. In this study, a modified version of the classification table of Erdey-Heydorn (2008) and Wienberg et al. (2013) gave the best results (Table 1).

\subsection{Seabed imagery}

Seabed imaging surveys were carried out with the Ocean Floor Observation System (OFOS) of the AWI deep-sea group. The OFOS setup and deployments were similar to those described by Bergmann and Klages (2012). OFOS is a surface-powered, deep-towed gear equipped with a highresolution (21 megapixel), wide-angle CANON ${ }^{\circledR}$ EOS 1Ds Mark III camera system. Towed behind the ship at a speed of $0.5 \mathrm{kn}$, OFOS was operated at a preferred height of $1.5 \mathrm{~m}$ above the seabed. For positioning, GPS fixes of the ship and water depth information were used. Water depth information was taken from an OFOS-mounted depth sensor and from the bathymetry data. The recorded high-resolution vertical seabed images show on average an area of $4.76 \mathrm{~m}^{2}$ $\left(\sigma=2.49 \mathrm{~m}^{2}\right)$. Three $50 \mathrm{~cm}$ spaced laser markers provided a scale in each photo. OFOS had two modes of operation. In automatic mode, a seabed photograph was taken every $30 \mathrm{~s}$ 
Table 1. Seabed classification catalogue modified after Erdey-Heydorn (2008). "100" represents one standard deviation of the standardised Benthic Position Index (BPI).

\begin{tabular}{|c|c|c|c|c|c|c|c|c|c|}
\hline \multirow{2}{*}{ Class } & \multirow{2}{*}{ Zone } & \multicolumn{2}{|c|}{ Fine BPI } & \multicolumn{2}{|c|}{ Broad BPI } & \multicolumn{2}{|c|}{ Slope in degrees } & \multicolumn{2}{|c|}{ Depth in metres } \\
\hline & & Lower & Upper & Lower & Upper & Lower & Upper & Lower & Upper \\
\hline 1 & Flat plains & -100 & 100 & -100 & 100 & & 5 & & -60 \\
\hline 2 & Broad slopes & -100 & 100 & -100 & 100 & 5 & 10 & & \\
\hline 3 & Steep slopes & -100 & 100 & -100 & 100 & 10 & & & \\
\hline 4 & Current scoured depressions & -100 & 100 & & -100 & & & & \\
\hline 5 & Scarp, cliff & & -100 & -100 & 100 & 10 & & & \\
\hline 6 & Depression & & -100 & & -100 & & & & \\
\hline 7 & Crevices, narrow gullies over elevated terrain & & -100 & 100 & & & & & \\
\hline 8 & Flat ridge tops & -100 & 100 & 100 & & & & & \\
\hline 9 & Rock outcrop high, narrow ridge & 100 & & 100 & & & & & \\
\hline 10 & Local ridge, boulders, pinnacles in depression & 100 & & & -100 & & & & \\
\hline 11 & Local ridge, boulders, pinnacles on broad flats & 100 & & -100 & 100 & & 5 & & \\
\hline 12 & Local ridge, boulders, pinnacles on slopes & 100 & & -100 & 100 & 5 & & & \\
\hline 13 & Local depression, current scours & & -100 & -100 & 100 & & 10 & & \\
\hline 14 & Plateau & -100 & 100 & -100 & 100 & & 5 & -60 & \\
\hline
\end{tabular}

along the transects. With a ship speed of $0.5 \mathrm{kn}$, the resulting average distance between seabed images was approximately $8 \mathrm{~m}$. In addition to the automatic mode, the camera was triggered manually, when the vertical ship's movement caused high variation of the height of the camera above the bottom (and consequently high variation in the area covered per image) and to record additional images from sites or organisms of specific interest.

In total, 1875 seabed photographs were taken along four transects on the northeast side of Nachtigaller Hill. Together, the photographs depicted more than $8900 \mathrm{~m}^{2}$ of seafloor. All transects were run downslope in south-north direction. The westernmost transect (185-1, Fig. 1) ranged from $36 \mathrm{~m}$ wd to $397 \mathrm{~m}$ wd and covered parts of the plateau and almost the entire slope along a distance of $4287 \mathrm{~m}$. Transect 189 (Fig. 1) was $1095 \mathrm{~m}$ long and covered only the upper slope between 29 and $186 \mathrm{~m}$ wd. The two easternmost transects (186-1 and 188-1, Fig. 1) partly overlapped and were combined $8224 \mathrm{~m}$ long. They ranged from $31 \mathrm{~m}$ wd on top of the hill, across the slope and the hill foot onto the background shelf at $413 \mathrm{~m} \mathrm{wd}$ (Fig. 1). Images that were taken too close to or too far away from the seabed were discarded from the analyses. To identify these pictures, the seabed footprint of each image was calculated, using the opening angle of the camera and its altitude above the seabed. After discarding the lower and upper fifth percentile of images closest and furthest from the seabed, a total of 1730 stills remained for the seabed image analyses.

\subsection{Seabed image analyses}

From each photograph, environmental and biological parameters were analysed. Due to the relevance of hard substrate for benthic species distribution, the abundances of ice rafted detritus (IRD) (i.e. boulders and pebbles) were semi- quantitatively assessed using the following categories: single boulders or gravel, boulder or gravel coverage of less than $10 \%, 10-30 \%, 30-50 \%, 50-70 \%, 70-90 \%$ and more than $90 \%$. IRD is the main source of hard substrate in the study area. In addition, broken-up outcropping rocks were mapped as hard substrate, but also as proxy for erosion processes. Soft substrate was categorised into sand and consolidated and soft fine sediment. The occurrence of sand (often with ripple structures) was regarded as evidence of winnowing and enhanced energetic regimes. Exposed consolidated sediments represented intermediate substrate (neither hard nor soft substrate) capable of forming steep cliffs and escarpments. Information on bioturbation and erosion processes was qualitatively extracted from the images (Fig. 3). Bioturbation represented intense burrowing in soft sediments. Ripples, only identified in sandy substrate, were indicative of lateral sediment transport and, thus, enhanced bottom currents. Erosion features and escarpments were proxies for enhanced bottom currents undercutting successions and forming cliffs. Trails of coarse sediments behind obstacles provided an additional proxy for moderately enhanced bottom currents. Striations on the seabed marked the impacts and scouring of icebergs (Figs. 3 and 4). Heavily bioturbated soft sediments on the foot of the hill and in the adjacent areas represented the background sedimentation.

For the biological analyses, the occurrences of the most abundant higher taxa (encrusting red algae, erected red algae, brown algae, sponges, hydrozoans, solitary ascidians, compound ascidians, gorgonians, bryozoans and ophiuroids) were semi-quantitatively assessed. For each seabed image, the seafloor cover of these taxa was estimated, serving as a gross proxy for biomass. Abundance categories were "absent", $1-5 \%, 6-30 \%$ and $>30 \%$ cover. Ophiuroids were categorised into "absent", 1-10, 11-100 and > 100 

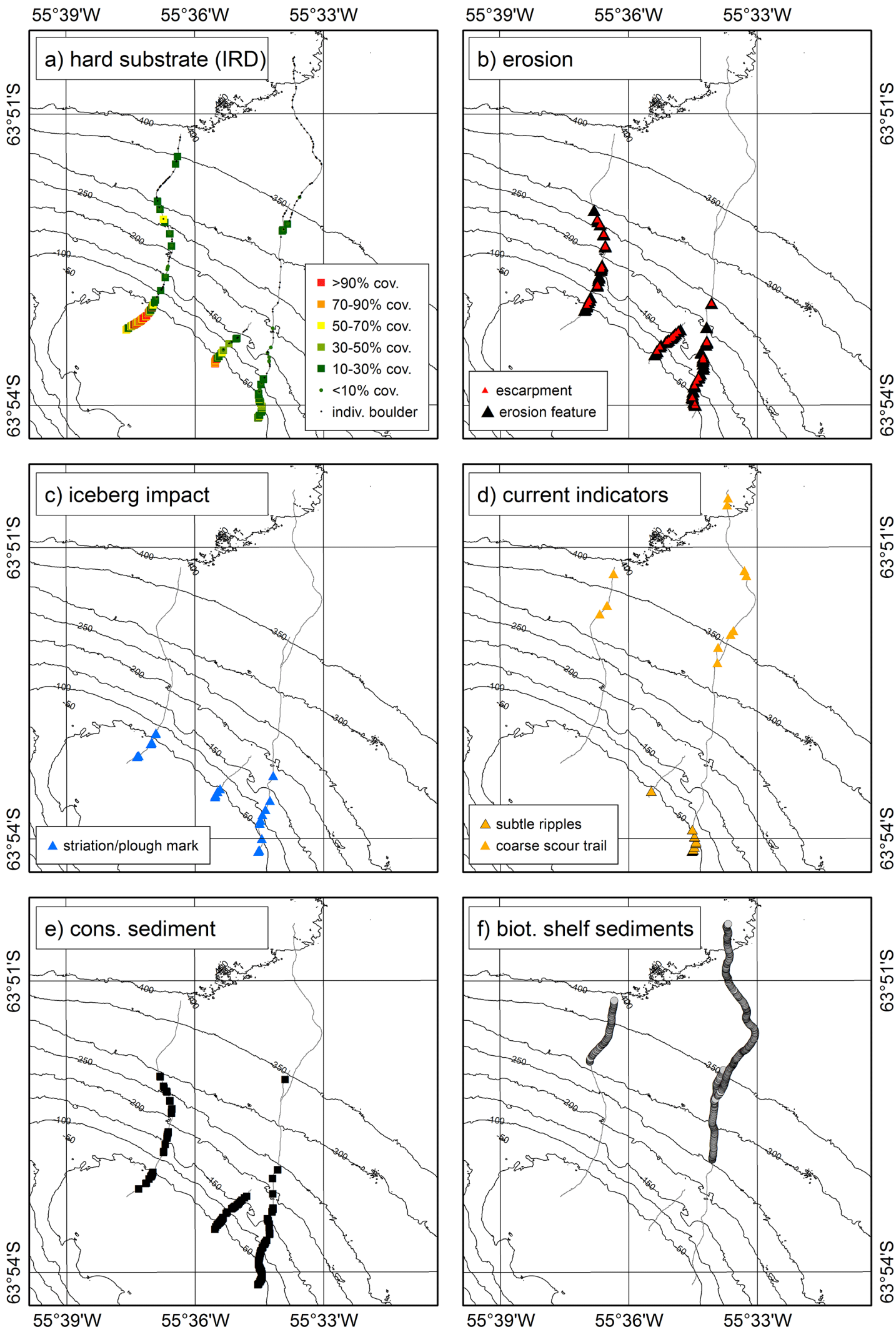

Figure 3. A selection of environmental parameters and proxies for environmental parameters along the OFOS transects. The coverage of hard substrate (a) in the form of boulders and pebbles was semi-quantitatively, visually estimated from the seabed images by one observer for consistency; (b, c) and (d) were qualitatively recorded and (e) and (f) represent background sediments in the OFOS images. Cons. = consolidated, biot. $=$ bioturbated, indiv. $=$ individual. 

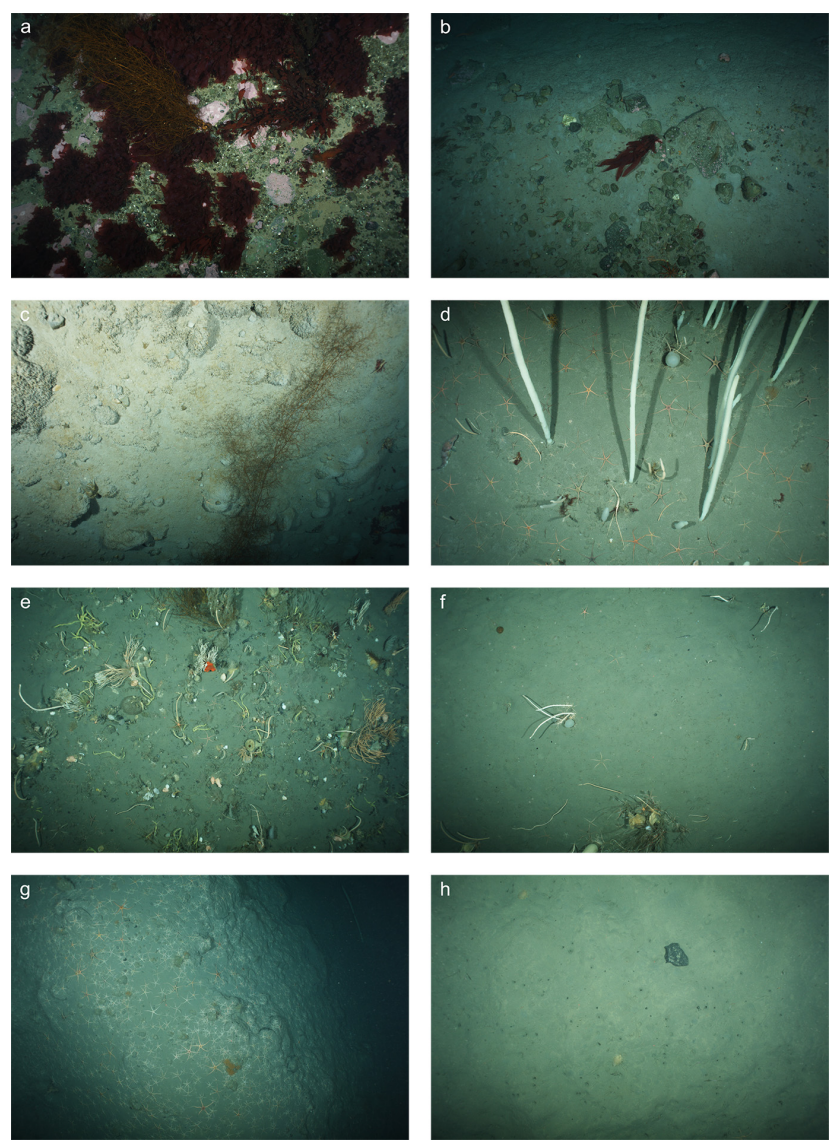

Figure 4. Selected seabed images of dominant benthic habitats. (a) Sheltered area on the plateau $(35 \mathrm{mwd})$, dense boulder and pebble coverage with abundant erect and encrusting red algae. (b) Exposed area towards the rim of the plateau ( $38 \mathrm{~m} \mathrm{wd}$ ). (c) Escarpment on the upper slope ( $56 \mathrm{mwd}$ ). (d, e, f) Benthic communities on the slope of the hill in $106 \mathrm{mwd}, 308 \mathrm{~m}$ wd and $313 \mathrm{mwd}$. (g) Erosional feature with exposed consolidated sediment at $241 \mathrm{~m}$ wd with abundant mobile fauna (mostly ophiuroids). (h) Background shelf setting at $403 \mathrm{~m}$ wd.

individuals per image, assuming that this abundance measure corresponded best with the seafloor cover of the sessile taxa. In addition, the number of animal phyla in each image was categorised into three classes (1-3 phyla, 4-8 phyla and $>8$ phyla per image) representing a gross indicator for overall biodiversity. In addition, the presence of brownish benthic diatom films on the sediment surface and the occurrence of very high abundances of suprabenthic krill ( $>200$ individuals per image) were also recorded. All results from the seabed image analyses were georeferenced and included in the GIS to generate maps of the relevant proxies and parameters (Fig. 5).

\subsection{Biostatistical analyses}

Correlations between biological and environmental data were calculated using the BIOENV routine of the statisti- cal package PRIMER (Clarke and Gorley, 2006). Similarities between images were calculated for both the biological data (using the Bray-Curtis index) and the environmental variables (after normalisation; using the Euclidean distance). The strength of the relationship between the biotic and environmental patterns was quantified with a Spearman rank correlation coefficient between all (chosen) biological parameters (taxa) and any number and combination of environmental parameters. The BIOENV computations were performed for any of the following combination of approaches:

1. for similarities based on (1) single photographs (representative of a $10 \mathrm{~m}$ scale) and (2) averages of groups of 10 adjacent photographs (representative of a $100 \mathrm{~m}$ scale);

2. for similarities based on (1) all photographs of single stations, (2) all photographs of the stations 186 and 188 combined (because they represent a continuous transect) and (3) all photographs of all four stations combined in one data set;

3. for similarities based on the (1) biomass proxies for all high taxa, (2) number-of-phyla classes.

Prior to the similarity calculations, data were transformed in cases of skewed distribution of values for environmental parameters. A square-root transformation was applied in the case of IRD and log transformations in the case of slope and seabed ruggedness. Environmental parameters without a standard deviation (only photographs with exclusively zero values within one data set) were eliminated from BIOENV computations.

The influence of the seabed terrain, expressed through the qualitative BTM classification scheme (Table 1), on the composition of the epibenthos, determined through the semiquantitative (0-3 scale) abundances of the most common higher taxa (see Sect. 2.6), was investigated by plotting the relative proportions of the selected taxa averaged within each BTM class. Moreover, within-BTM averages of the abundance of each selected taxon were computed and plotted to analyse potential distribution preferences of the taxa for certain BTM types.

\subsection{Hydrographic data}

The hydrographic water column profiles were recorded with a Seabird ${ }^{\circledR}$ SBE911 plus CTD probe. To determine the distance to the seabed, a Benthos ${ }^{\circledR}$ altimeter was mounted on the CTD. All CTD casts were performed for the full water column less a safety distance to the seabed of 1-2 $\mathrm{m}$.

\section{Results}

Nachtigaller Hill is a flat-topped, truncated NW-SE striking, elongated elliptical geomorphological feature seated in 
ca. $350 \mathrm{~m}$ wd on the over-deepened shelf of the northwest Weddell Sea (Fig. 1). It measures ca. $15 \mathrm{~km}$ along its main axis and ca. $9.5 \mathrm{~km}$ across according to the $350 \mathrm{~m}$ depth contour. Morphologically, the hill can be divided into three main units: the flat summit area (further referred to as plateau), the slopes down to approximately $250 \mathrm{~m}$ wd and the hill foot $250-350 \mathrm{~m}$ wd. Beyond the hill foot is the background shelf setting (Fig. 1).

\subsection{Plateau}

\subsubsection{Morphology}

The plateau measures ca. $6.9 \mathrm{~km}$ along its main axis and ca. $2.7 \mathrm{~km}$ across, covering an area of ca. $15.4 \mathrm{~km}^{2}$. Water depths on the plateau are on average $43 \mathrm{~m}$ and range from $20 \mathrm{~m}$ to $50 \mathrm{~m}$ (Fig. 1). Seabed inclination hardly exceeds $5^{\circ}$ (Fig. 2). Consequently, the broad-scale BPI represents the plateau as a smooth homogeneous area. Only the finescale BPI and the terrain ruggedness highlight local variations (Fig. 2). These local variations are low, metres-scale ridges and shallow troughs that can also be identified on the seabed images (Fig. 4). Due to better multibeam coverage, these ridges and troughs are more obvious in the northeast than in the southwest sector of the plateau.

In the BTM, "plateau" is an individual seabed category that represents the central part of the hill (Fig. 2). The rim of the plateau is classified as "flat ridge tops" (Fig. 2). This is due to the abrupt change in morphology from the plateau to the slope and the resulting convexity of the seabed. In addition to the rim of the plateau, the northwest slope and the upper southeast slope are also classified as "flat ridge tops" (Fig. 2). Unfortunately, no seabed images are available for ground-truthing of this seabed class. Due to the prevailing ice conditions at the time of the OFOS surveys, these parts of the Nachtigaller Hill were inaccessible and thus not covered by any OFOS transect.

\subsubsection{Substrate}

At water depths shallower than $50 \mathrm{~m}$, iceberg scouring and winnowing are the dominant process affecting sedimentological and biological processes. Consequently, all surveyed areas on the plateau show strong influences of erosion indicated by coarse lag deposits and exposed consolidated and lithified sediments. Gravel and boulder pavements are common in the shallow depressions and troughs. Sand patches with subtle but recognisable ripples are less common but also present on the plateau, indicating sediment transport due to enhanced bottom currents. Abrasions by icebergs at the crest of low ridges expose consolidated fine sediments (Figs. 3 and 4).

\subsubsection{Biology}

Encrusting and erect red as well as brown algae occur with low to moderate seabed abundances on the plateau (Fig. 5a- c). At transect 186, brown algae are abundant on several seabed images covering $>30 \%$ of the seafloor. The biodiversity on the plateau is generally low, with less than eight animal phyla encountered (Fig. 5d). Occasionally, low abundances of sponges and compound ascidians have been recorded from sheltered areas (Fig. 5e and h). Ophiuroids occur in varying numbers. Along transect 185 their numbers increase towards the rim of the plateau. At comparable sites along transects 186 and 189 their numbers are however low (Fig. 5k). Hydrozoans, solitary ascidians, gorgonians and bryozoans are almost absent from the plateau area (Fig. 5f, $\mathrm{g}, \mathrm{i}$ and $\mathrm{j}$ ).

\subsection{Slope}

\subsubsection{Morphology}

Beyond the clearly defined edge of the plateau, the seabed drops in 4-6 terraces to approximately $300 \mathrm{~m}$ wd (Fig. 1). In general, the slopes can be characterised as geomorphologically variable and rugged terrain (indicated by the ruggedness data and the fine-scale BPI, Fig. 2d and f). Also consecutive seabed photographs often show characteristics of different terrains (Fig. 5) thus highlighting the high variability of the geomorphology. From the bathymetric data, the slope can be subdivided into a steep upper slope (down to ca. $150 \mathrm{~m}$ ) where seabed inclinations often exceed $20^{\circ}$ and a lower slope with $3-5$ flat terraces $\left(0-5^{\circ}\right)$ separated by escarpments with approximately $10-20^{\circ}$ inclination (Figs. $2 \mathrm{~b}$ and 4). This terraced slope geomorphology is also pronounced in the broad-scale BPI raster and consequently in the seabed classification (Fig. 2c and e). In addition to the general terrace structure (flat areas separated by steeper areas, Fig. 2), small ridges and troughs create a very rugged heterogeneous terrain. These patterns are also reflected in the seabed classification where the slopes are characterised by the seabed classes "broad slopes" and "flat terrain" (Fig. 2). The steps between the terraces are classified as "steep slopes" and on the upper slopes as "escarpment, cliff" (Fig. 2). Some areas with distinct broad-scale concave morphology are classified by the BTM as "current scoured depression" (Fig. 2).

\subsubsection{Substrate}

On the hill slopes, the effect of iceberg scouring is mainly restricted to the areas shallower than $100 \mathrm{~m}$ wd and generally decreases away from the plateau (Fig. 3c). In the same way, the abundance of hard substrate in the form of IRD decreases and hardly exceeds $50 \%$ coverage on the slopes (Fig. 3a). In addition to IRD, consolidated sediments exhumed by erosion occur in many places on the slope (Figs. 3e and 4) often forming steeply inclined seabed (Fig. 2b). 

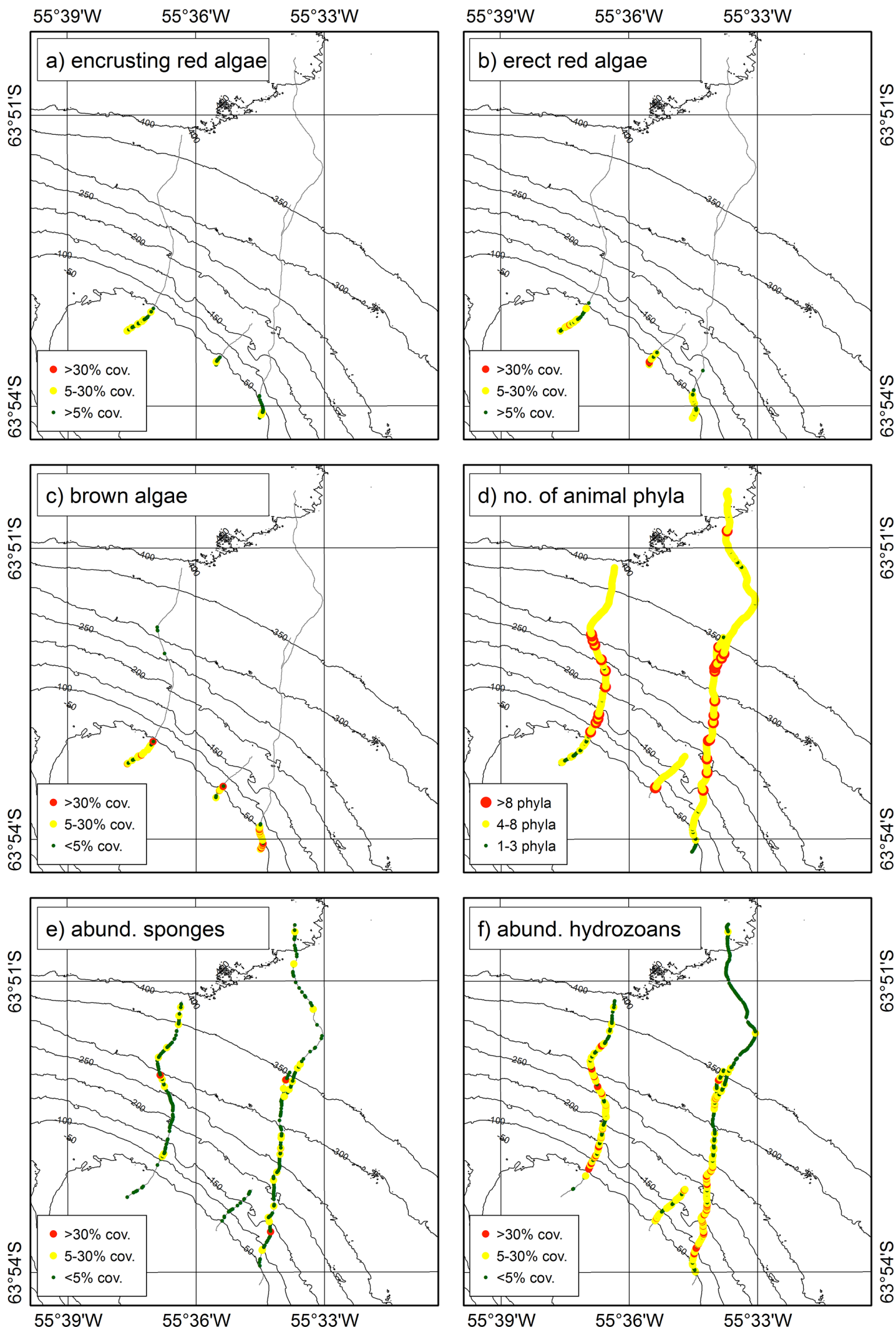

Figure 5. Abundances of algae (a-c) and benthic organism groups (e-l) along the OFOS transects. (d) Number of animal phyla in each image. This information is an indicator for the distribution of biodiversity on the hill. Abund. $=$ abundance, sol. $=$ solitary, com. $=$ compound, cov. $=$ coverage indiv.$=$ individuals . 

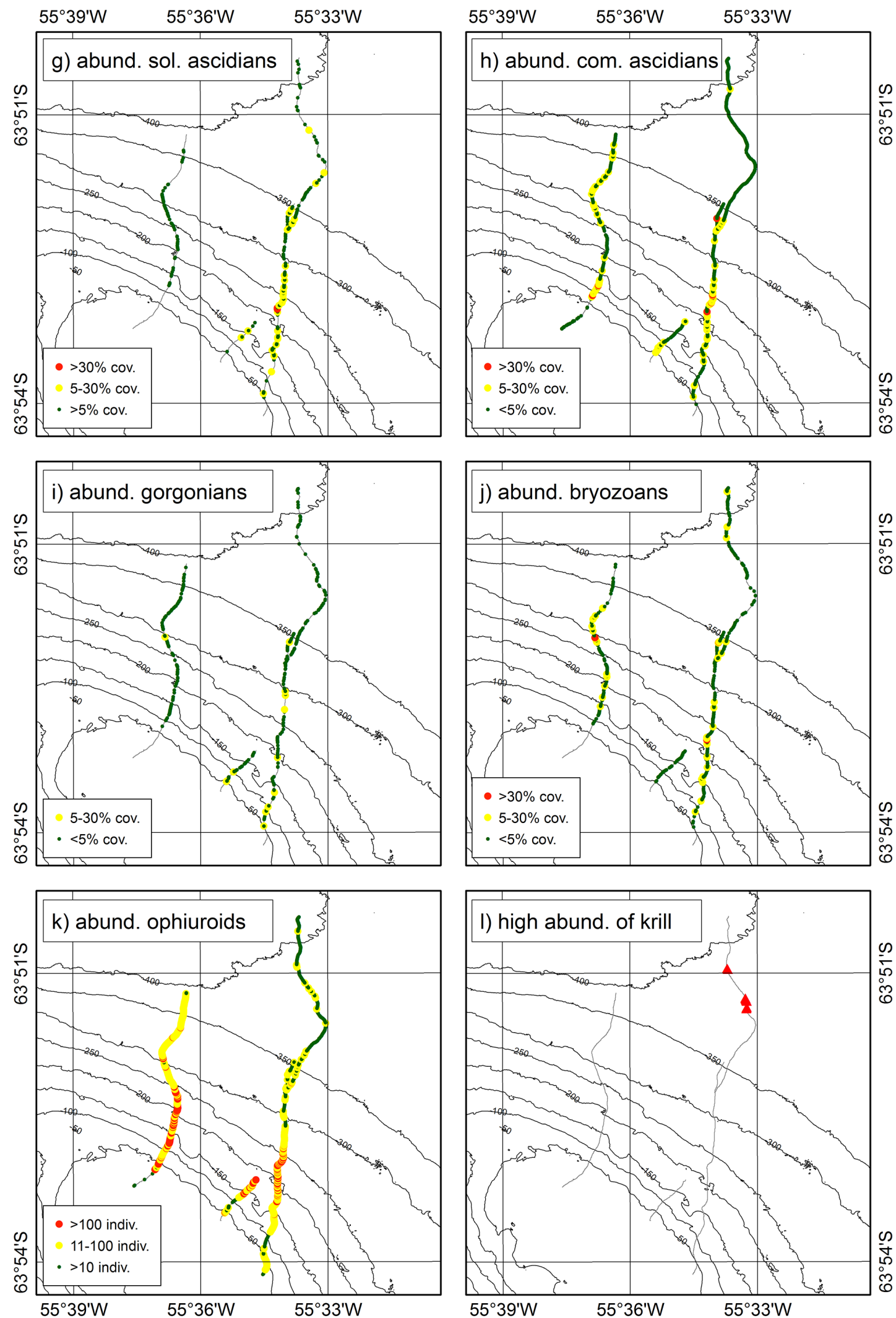

Figure 5. Continued. 


\subsubsection{Biology}

The hill slope shows the highest diversity of phyla (often $>8$ animal phyla per image, Fig. 5d). Hydrozoans and ophiuroids are generally more abundant at the slope than at the shallower and deeper parts of the transects (Fig. $5 \mathrm{j}$ and k). Most of the other animal groups (compound ascidians, bryozoans, and sponges) show higher abundances only on a few photographs. Solitary ascidians are mostly moderately abundant (Fig. 5g). Only along transects 186/188, in a few places, do high abundances occur where also gorgonians are more abundant (Fig. 5i). Generally these taxa show the least distinct depth zonation. In many cases, faunal abundances vary greatly, even between consecutive images. Ophiuroids at the upper to intermediate slope seem to be most equally distributed at a high abundance level (Fig. 5k).

\subsection{Hill foot and background shelf setting}

\subsubsection{Morphology}

The hill foot below $300 \mathrm{~m}$ wd in the NW and $250 \mathrm{~m}$ wd in the SE of the study area is generally less than $5^{\circ}$ inclined. In this area, several small, irregular escarpments with $5-10^{\circ}$ inclination are found (Fig. 2b). The background shelf setting is characterised by smooth even seabed (slope angles $<5^{\circ}$ ). As opposed to the foot of the hill, small escarpments are absent. Only in the northeast corner of the multibeam coverage, do the sides of a trench-like feature display slope angles of 5$10^{\circ}$. This feature is likely to be the scour mark of a large iceberg (Fig. 2b). The unrealistically smooth areas on the southwest slope, south of $63^{\circ} 55^{\prime} \mathrm{S}$ are grid integration artefacts outside the multibeam coverage not representing the true geomorphology (Figs. 1 and 2).

\subsubsection{Substrate}

The foot of the hill is characterised by strongly bioturbated sediments similar to the general background sedimentation (Fig. 3f). In this area, hard substrate only occurs in the form of IRD. Trails of coarse sediment behind some boulders (Fig. 3d) indicate that bottom currents are at least temporarily sufficient to remove fine material and to form scours around obstacles.

\subsubsection{Biology}

With the exception of the shallowest quarter, transect 188 covers the hill foot and background shelf surroundings. In this area the number of phyla is moderate (Fig. 5d). Abundances of all animal taxa are generally lower than at the slope. Only ophiuroids show moderate abundances at the deepest part of transect 185 and occasionally at transect 188 (Fig. 5k). Sponges are generally characterised by moderate seabed coverages on single photos taken at the deepest section of the transects (Fig. 5e). Like solitary ascidians and gor- gonians, they are also absent from several images at the hill foot and shelf setting. In contrast, ophiuroids hydrozoans and compound ascidians are present in almost all images. A few photographs show high abundance of krill swimming close to the seabed at depths between $373 \mathrm{~m}$ wd and $385 \mathrm{mwd}$ (Fig. 51).

\subsection{Biostatistics}

The best and second best correlation results for all 24 parameter combinations (see materials and methods) for each run are listed in Table 2. Some of these correlations were moderate $(\rho=0.5-0.722)$, some were only poor $(\rho<0.5$; not shown in Table 2). For most of the individual computations, the ranking of correlations shows no discrete step between "moderate" and "poor" correlations. Instead, the values for the correlation coefficient decrease continuously. Furthermore, the results differ considerably among the different approaches used (single photographs, averages of bins of 10 successive photographs, diversity and community approach). Since no clear result was obtained, an overarching analysis for the transects (186 and 188 considered as one transect) was conducted for the community approach. Only runs yielding correlation coefficients $>0.5$ were considered. All environmental factors were counted that contributed to these results within the single approaches.

Biotic distribution patterns are best explained by the abundance of IRD, followed by water depth. The parameters "escarpment", "current", "ruggedness" and "seabed classification" are never among any of the two best correlations. All remaining environmental parameters show only poor relationships to the distribution pattern in the biological data.

In the case of the computations based on the number of phyla (diversity approach), the correlation coefficients of all individual results are too small to be used as a basis for a further comprehensive analysis. Alternatively, data were pooled for all images, independently of the transect. Results with a correlation coefficient $>0.5$ were only obtained for 10-binned photograph runs. These calculations returned better correlations for biological seafloor cover (or proxy) than for the number of phyla. The relevant environmental factors of both approaches are, however, similar. IRD, consolidated sediment, striated seabed (iceberg scouring) and ripples are relevant in all of the four computations. Sand and slope are relevant in three computations, and soft sediment, depth, slope and ruggedness in only $\leq 2$ runs.

The influence of the seabed terrain on the abundance and composition of the epibenthos was investigated for the six most frequent BTM classes (1, 2, 3, 8, 10, and 12; see Table 1 for explanation). Between 87 and 800 seabed photographs were designated to the individual BTM classes. BTM classes with lower frequencies were assumed to provide spurious results and, hence, excluded. The bar chart of the relative abundance proportions of the most abundant higher taxa averaged within each selected BTM class (Fig. 6a) shows that 
Table 2. Calculations of correlation between environmental factors and epibenthic taxa. Results in grey were not considered for further analyses or detailed interpretation due to low $(<0.5) \rho$ values. Abbreviations for environmental factors are biot: bioturbation, BTM: benthic terrain modeller seabed classification, cons: consolidated sediment, depth: water depth, eros: erosion (e.g. disturbed seabed, scours), esca: escarpment (steeply inclined seabed, cliff), IRD: ice rafted detritus, ripl: ripple marks due to bottom current activity, rug: ruggedness of the seabed, sand: sandy surface sediments, slope: seabed inclination, stri: striation on the seabed due to iceberg scouring. In the Approach column, " 1 " stands for the analyses of single, and " 10 " for 10-pooled photographs. COM stands for the analyses considering abundance classes of all higher benthic taxa, the community; DIV for "biodiversity", here defined by the number of phyla.

\begin{tabular}{|c|c|c|c|c|c|}
\hline $\begin{array}{l}\text { OFOS } \\
\text { transect }\end{array}$ & Approach & $\rho$ & $\begin{array}{l}\text { Environmental factors that explain best } \\
\text { benthic patterns (first and second best) }\end{array}$ & $\begin{array}{l}\text { Transformation log (IRD + 1) } \\
\log (\text { rugg) } \log \text { (slope) }\end{array}$ & $\begin{array}{l}\text { No. of env. } \\
\text { factors }\end{array}$ \\
\hline 185 & 1_COM & 0.640 & $\begin{array}{l}\text { IRD, depth } \\
\text { IRD, sand, depth }\end{array}$ & Slope, rugg & 13 \\
\hline 186 & 1_COM & $\begin{array}{l}0.516 \\
0.514\end{array}$ & $\begin{array}{l}\text { IRD, cons, sand, ripl, depth } \\
\text { IRD, cons, sand, depth }\end{array}$ & IRD, rugg & 13 \\
\hline 189 & 1_COM & $\begin{array}{l}0.656 \\
0.654\end{array}$ & $\begin{array}{l}\text { IRD, stri, ripl } \\
\text { IRD, ripl }\end{array}$ & Rugg & 10 \\
\hline 185 & 10_COM & $\begin{array}{l}0.718 \\
0.712\end{array}$ & $\begin{array}{l}\text { IRD, biot, stri } \\
\text { IRD, biot, stri, depth }\end{array}$ & Slope, rugg & 13 \\
\hline 186 & 10_COM & $\begin{array}{l}0.725 \\
0.721\end{array}$ & $\begin{array}{l}\text { IRD, cons, sand, soft, ripl } \\
\text { IRD, cons, soft, ripl }\end{array}$ & Slope, rugg & 13 \\
\hline 189 & 10_COM & $\begin{array}{l}0.705 \\
0.704\end{array}$ & $\begin{array}{l}\text { IRD, soft, eros, stri, depth, slope } \\
\text { IRD, eros, stri, depth, slope }\end{array}$ & IRD, rugg, slope & 10 \\
\hline $186 \& 188$ & 10_COM & $\begin{array}{l}0.722 \\
0.720\end{array}$ & $\begin{array}{l}\text { IRD, cons, sand., soft, biot, ripl, slope } \\
\text { IRD, cons, soft, biot, ripl, slope }\end{array}$ & IRD, slope, rugg & 13 \\
\hline 189 & 1_DIV & $\begin{array}{l}0.675 \\
0.656\end{array}$ & $\begin{array}{l}\text { IRD, stri, ripl } \\
\text { IRD, stri }\end{array}$ & Rugg & 10 \\
\hline 189 & 10_DIV & $\begin{array}{l}0.675 \\
0.672\end{array}$ & $\begin{array}{l}\text { IRD, stri } \\
\text { IRD, stri, slope }\end{array}$ & IRD, Rugg, slope & 9 \\
\hline $186 \& 188$ & 10_DIV & 0.519 & Sand, ripl & IRD, slope, rugg & 13 \\
\hline All & 10_COM & $\begin{array}{l}0.714 \\
0.714\end{array}$ & $\begin{array}{l}\text { IRD, cons, sand, soft, stri, ripl, depth, rugg } \\
\text { IRD, cons, sand, soft, stri, ripl, depth, slope }\end{array}$ & IRD, slope, rugg & 13 \\
\hline All & 10_DIV & $\begin{array}{l}0.506 \\
0.504\end{array}$ & $\begin{array}{l}\text { IRD, cons, sand, stri, ripl, slope } \\
\text { IRD, cons, stri, ripl, slope }\end{array}$ & IRD, slope, rugg & 13 \\
\hline
\end{tabular}

epibenthic composition did not differ much between the terrain types, except for BTM class 8 (flat-top ridges) where algae are abundant, while they are rare or absent in the other BTM classes. The compound bar chart of the within-BTM averages abundances of the epibenthic taxa (Fig. 6b) also indicates the pronounced preference of algae for BTM class 8 , since this terrain type is confined to the shallow plateau where enough sunlight penetrates to the seabed to allow for the occurrence of primary producers. In contrast, the other epibenthic taxa are recorded with higher abundances in the other five selected BTM classes, a pattern that is evident for the most abundant taxa, hydrozoans and ophiuroids. These taxa reach highest densities in photos depicting "steep slopes" (BTM class 3 ) and at "local ridges, boulders, pinnacles on slopes" (BTM class 12).

\subsection{Local hydrography}

All water column profiles (Fig. 7a) show strong local effects due to the influence of Nachtigaller Hill acting as obstacle to the general southwest to northeast flow patterns in the area (Absy et al., 2008; Schröder et al., 2002). This influence de- creases with increasing distance to the hill. The hydrographic conditions around Nachtigaller Hill are dominated by low saline and cold shelf waters that affect the top $500 \mathrm{~m}$ of the water column (Absy et al., 2008). Depending on the local winter conditions and sea ice cover, the influence of the Winter Water is detectable in the top 100 to $150 \mathrm{~m}$ in some profiles (Fig. 7).

The profile from station 189-2 represents the local hydrography above the plateau. Despite some highly variable surface effects, all measured parameters show a well-mixed, homogeneous water column above the plateau. A typical warm surface layer was not present at the time of the survey in the middle of the austral summer (Fig. 7b-d). The stations 1651 and 185-5 represent the hydrographic regime above the downstream slopes of the hill. The potential bottom water temperatures and salinities change by $\sim 0.3{ }^{\circ} \mathrm{C}$ and $0.14 \mathrm{psu}$ across the slope (Fig. 7c and d). These profiles display the perturbation of the hydrographic regime above the hill flanks. Station 190-1 already shows strong influences of the regional oceanography expressed by a perturbation of the background water column structure by the Nachtigaller Hill acting as an 

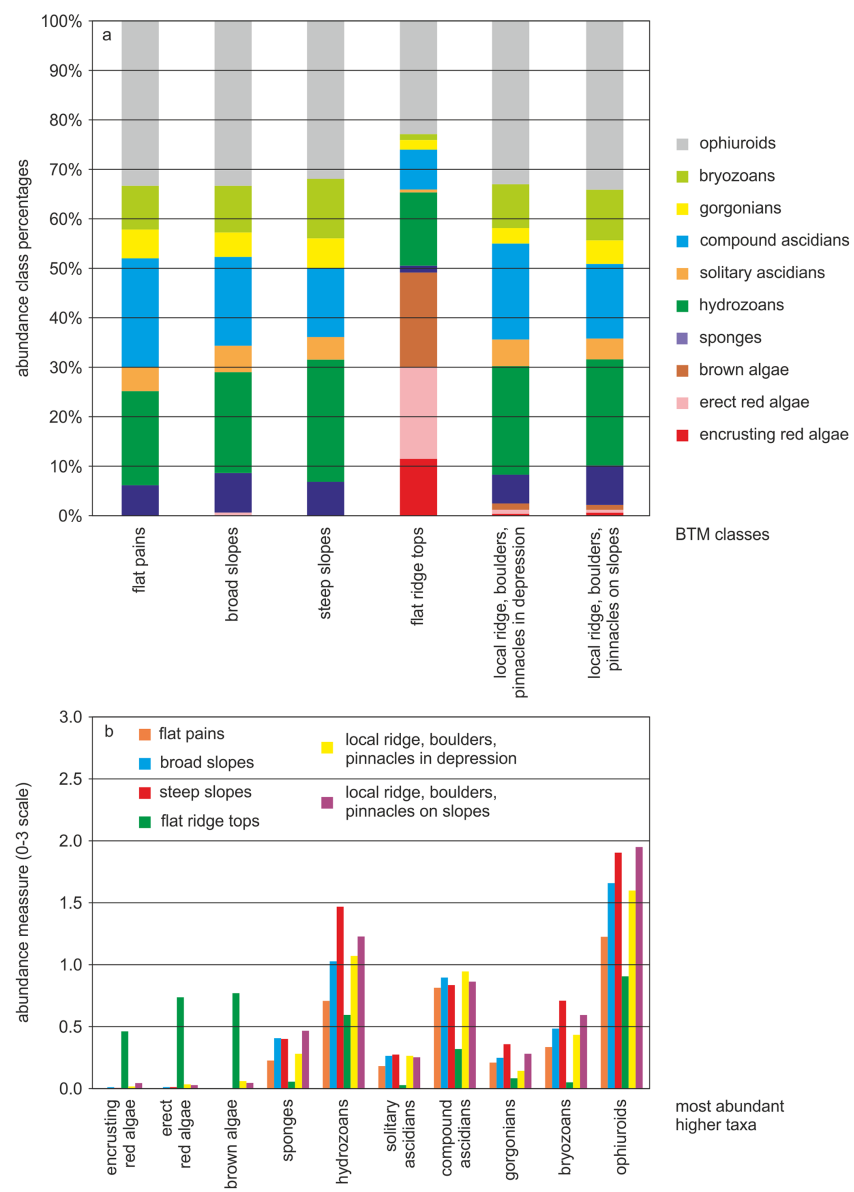

Figure 6. Relationship between seabed terrain, expressed through the qualitative benthic terrain modeller (BTM) classification scheme (Table 1), and the abundance and composition of the epibenthos, determined through the semi-quantitative ( $0-3$ scale) abundances of the most common higher taxa. (a) Relative proportions of the selected taxa averaged within six selected BTM classes. (b) Within-BTM average abundances of the selected taxa, computed for six selected BTM classes.

obstacle to the general flow patterns in the area (Fig. 7c-d). At this station, between 100 and $200 \mathrm{~m}$ wd, the excursions in the potential temperature clearly display the interleaving of local and mechanically disturbed water at the hill site with the undisturbed background waters of the surrounding shelf setting (Fig. 7c). Also the mixed layer, deepening from station $165-1$ to $185-5$ and to $190-1$, indicates the decreasing effect of the local hydrography away from Nachtigaller Hill (Fig. 7c-d).

\section{Discussion}

The newly discovered Nachtigaller Hill offers special habitats for benthos communities on the over-deepened shelf of the Weddell Sea. Largely isolated from coastal influences, this offshore site is a representation of benthic community
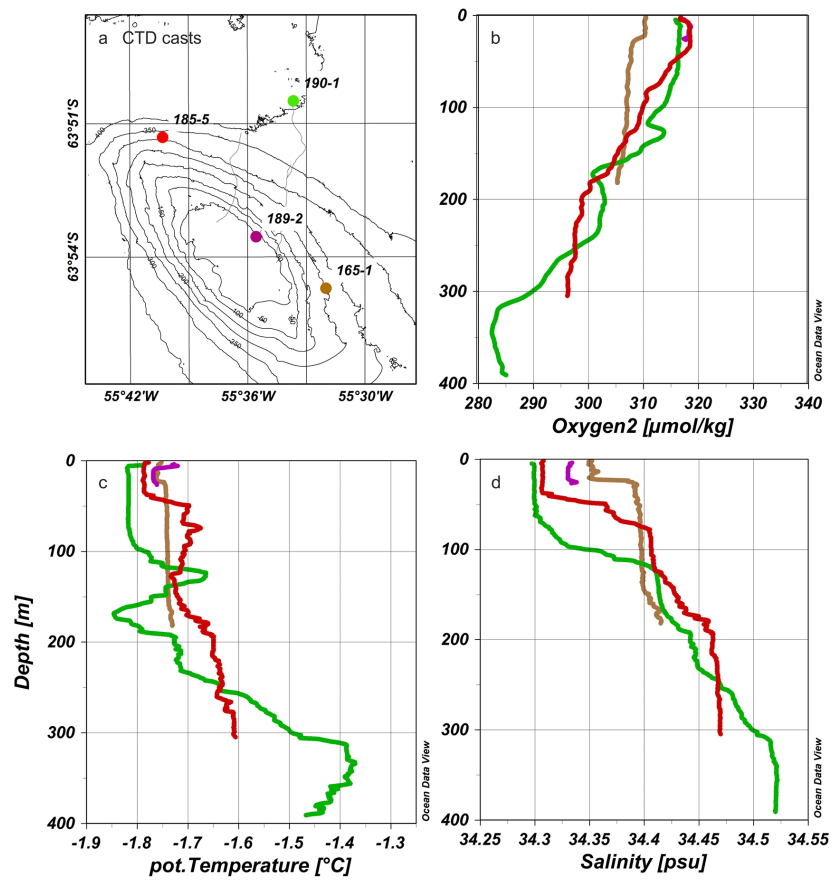

Figure 7. Water-column profiles of oxygen concentration, potential temperature and salinity from four sites on and off the Nachtigaller Hill. The profiles from the hill site show the local hydrographic conditions. Water column profile 190-1 furthest away from the hill already shows the transition from local hill-controlled hydrography to the general oceanographic conditions in the area. This effect is most pronounced in the potential temperature (C).

structures and habitat zones in a seasonally to perennially ice covered, stable high-latitude Antarctic setting.

\subsection{Epibenthos communities}

In total, the bottom fauna of the Nachtigaller Hill can be considered as a mixture of benthic assemblages known from all around the Antarctic continent (Gutt, 2006). A variety of community types classified by Gutt et al. (2013a) co-occur in the relatively small area. They include "sessile suspension feeders with associated fauna" dominated by sponges or other sessile epibenthic organisms or "mobile deposit feeders and in-fauna". "Mobile deposit feeders and in-fauna" are represented by "bioturbated sediment" and "monospecific" and "physically controlled" assemblages as well as those with very low biomass or absence of trophic guilds. Typical shallow-water elements, such as micro- and macroalgae, occur in high abundances in sheltered areas on the plateau. However, two prominent cnidarian taxa, Tubularia (Hydrozoa) and the octocoral Clavularia (Anthozoa) that are often most abundant in Antarctic shallow waters (Raguá-Gil et al., 2004 and references therein), have not been found at the Nachtigaller Hill. These taxa occur off the Antarctic Peninsula but also, albeit less abundant, in the eastern Weddell Sea, while they are absent in the central Weddell Sea (Raguá-Gil 
et al., 2004 and references therein) as well as on the Nachtigaller Hill (this study). There are two possible explanations for their absence from Nachtigaller Hill. Firstly, the dispersal of these taxa is so limited that they cannot overcome the distance of approximately $70 \mathrm{~km}$ between the coastal zones of the Antarctic Peninsula and the Nachtigaller Hill. Their occurrence in the eastern Weddell Sea must then be supported by the inflow of dispersal stages from a shallow-water population located relatively nearby on the shallow shelf off East Antarctica via the eastward coastal current.

Secondly, assuming that these taxa may generally be capable of a long-range dispersal (over the distance between the west coast of the Antarctic Peninsula and the Nachtigaller Hill or between the Four Season Hill and the Nachtigaller Hill via the clockwise flowing Weddell Gyre) then the alternative explanation is that specific ecological conditions do not allow for a successful settlement of these animals on Nachtigaller Hill despite the similarity in the environmental conditions at the Four Season Hill and at the Norsel Bank in the eastern Weddell Sea (Fig. 1),. The Four Season Hill is, however, located much closer to the coast (Raguá-Gil et al., 2004) than the Nachtigaller Hill. In general, the epibenthic communities at Nachtigaller Hill are more similar in composition to those of the Antarctic Peninsula (Gutt et al., 2013b; Piepenburg et al., 2002; Raguá-Gil et al., 2004) than to those of the eastern Weddell Sea (Gerdes et al., 1992; Gutt, 2007; Gutt et al., 2013b).

This is evidence that the Nachtigaller Hill has mainly been colonised by dispersal stages originating from the eastern Antarctic Peninsula that were transported perpendicular to the prevalent northward flowing currents of the western branch of the Weddell Gyre. The position of the Nachtigaller Hill in the extension of the Antarctic Sound could also facilitate recruitment with larvae from the western side of the Antarctic Peninsula. This hypothesis remains speculative as the dispersal route would be opposite to the generally westward flowing currents in the Antarctic Sound. It can, however, not be ruled out due to the turbulent hydrographic conditions in the Antarctic Sound (Sangrà et al., 2014). Colonisation by larvae from the southeast and southern Weddell Sea via the Weddell Gyre is also possible but less likely because of the much longer distance between the source region and the Nachtigaller Hill.

Other faunistic elements typical of the high-latitude Antarctic benthos are rare at the Nachtigaller Hill. Glass and demosponges, for example, occur at very high abundances in several locations around the Antarctic continent, e.g. the eastern Weddell Sea (Gerdes et al., 1992; Gutt, 2007; Gutt et al., 2013b), but only play a minor role at the Nachtigaller Hill. Typical high-latitude gorgonians (e.g. the genera Thouarella and Dasystenella) with distribution patterns similar to the sponges occur on both sides of the Antarctic Peninsula (Gutt et al., 2013b; Lockhart and Jones, 2008). They are also not abundant on Nachtigaller Hill.
On a side note, high abundances of krill have been observed at three locations on the shelf to the northeast of the hill at $400-420 \mathrm{~m}$ wd. The phenomenon that krill can regionally aggregate at unusually deep sites close to the sea floor is known to occur at some sites in the Weddell Sea and around the Antarctic Peninsula. It has been reported from fjords (Grange and Smith, 2013), the shelf (Schmidt et al., 2011) and abyssal depths (Clarke and Tyler, 2008) west of the Antarctic Peninsula and the deep shelf of the southeast Weddell Sea (Gutt and Siegel, 1994). Along the remaining transects, krill has only occurred sporadically and in low numbers. This krill might have been attracted by the light of the OFOS but must have been in the vicinity in the first place.

\subsection{Benthic habitats and environmental drivers}

The Nachtigaller Hill can be broadly depth-related classified into plateau, upper slope, foot and background setting. The results from analyses of the terrain (Fig. 2) and the seabed imagery (Fig. 4) both show that the hill is highly complex in terms of small-scale geomorphology, seabed classes, substrate and benthic community distribution. This complexity is captured in the seabed classification based on the incorporation of the fine-scale BPI in the BTM.

In terms of habitat characterisation, the plateau of Nachtigaller Hill is completely in the photic zone, hence the presence of macroalgae and diatom layers (Fig. 5). In general, light levels are a function of the water depth, turbidity and, in polar regions, also of ice cover (Wulff et al., 2009). In addition, the presence of macroalgae can be used to indicate the light level critical for photosynthesis (Gómez et al., 1997). In general, off the Antarctic Peninsula large macroalgae like Himantothallus grandifolius have been found at water depths up to $90 \mathrm{~m}$, and smaller foliose and filamentous algae can occur at even greater depths (Wiencke et al., 2007). Due to the shallow water depth, and similar to most shallow areas on the Antarctic shelves, the impact of iceberg scouring (e.g. Gutt, 2000; Thatje et al., 2005; Wiencke et al., 2007) is very likely another dominant control on habitat distribution on the hilltop plateau. Thus, the strongest contrast is between elevations exposed to frequent iceberg scouring and areas sheltered by elevations and ridges. Wave action is another disturbance that potentially affects the fauna living on the plateau. It can, however, not directly be measured or observed and separated from icebergs disturbance. Although the BTM classifies the central part of the plateau as "flat plateau", the "local ridges on broad flats" and "local depressions" reflect the fine-scale structure of habitat distribution (Fig. 2) seen in the seabed images. Accordingly, in the sheltered depressions, the seabed is covered by abundant IRD often in the form of boulder and gravel pavements. On the ridges and in less sheltered areas, consolidated sediments are exposed (Fig. 3). Towards the rim of the plateau, IRD becomes less abundant and consolidated sediments prevail (Fig. 3). Macroalgae and sessile organisms are limited 
to sheltered areas there (Figs. 2-5). Sessile organisms generally only occur in low abundance and only a small proportion of the available hard substrate is colonised. Similar to other areas affected by iceberg scouring (Cummings et al., 2010; Gutt, 2000; Starmans et al., 1999), the occurrence of sessile organisms is controlled by environmental stress rather than by the substrate on the plateau of Nachtigaller Hill. As a result of the repeated disturbance in the exposed areas, only mobile fauna can be found.

The hill slopes cross several environmental gradients. The presence of algae down to $56 \mathrm{~m}$ wd on the northern transect and down to $72 \mathrm{mwd}$ on the southern transect (brown algae attached to boulders found at $240 \mathrm{~m}$ wd must have been displaced by icebergs, Fig. 5a) indicates that the uppermost parts of the slopes are still within the photic zone. This depth distribution of the macroalgae is in good agreement with findings from King George Island (Gómez et al., 1997), although there, most occurrences were limited to $<40 \mathrm{~m} \mathrm{wd}$. Fischer and Wiencke (1992), however, reported occurrences of macroalgae down to $90 \mathrm{~m}$ wd in this area based on dredge samples. The hydrographic conditions are rather constant across the slope with the temperature only rising by $\sim 0.3^{\circ} \mathrm{C}$ and the salinity decreasing by $\sim 0.14$ psu from the foot of the hill towards the plateau (Fig. 7c and d).

Similar to other submarine hills and seamounts (Bowden et al., 2011; Pitcher et al., 2007; Rogers, 1994), the slopes of Nachtigaller Hill are geomorphologically more complex than the plateau. Very steep and rugged terrain just below the rim of the plateau, is likely formed by continuous iceberg scouring. The areas with the highest ruggedness are classified as "rock outcrops" (Fig. 2). This classification is in good accordance with the data from the seabed imaged analyses that show common erosion features and escarpments (Fig. 3). It furthermore supports what is known from other Antarctic seamounts and seamounts in general where erosional processes on the flanks of the mounts have resulted in complex geomorphologies with escarpments, crevices, knolls and terraces (Bowden et al., 2011; Pitcher et al., 2007) thus providing a patchwork of habitats. Areas classified as "current scoured depression" are also common on the upper slope. At Nachtigaller Hill, they probably also indicate slope failures and small slides. This interpretation is supported by seabed images showing slide structures from the upper slopes (Fig. 4c). These slides are probably triggered by iceberg scouring. At the time of the survey several icebergs were grounded on the upper slope of the hill. In terms of habitat distribution, the entire upper slope can be interpreted as a highly fragmented habitat. The delineation of smaller subunits based on seabed classification and imagery was scarcely possible as these parameters show no distinct spatial correlation and often vary from image to image which would mean from pixel to pixel in the classification raster. This complexity is also apparent in the correlation of biological and environmental parameters later in the text. On the upper slopes, hard substrate is abundant in the form of consoli- dated sediment and IRD (Fig. 3). Similar to what is described from the Admiralty and Scott Island Seamounts (Bowden et al., 2011) the available hard substrate is, however, not fully colonised. In comparison with the upper slope, the terrain of the lower slope is less rugged with more gradual changes between "broad slopes" and "flat plains" (Fig. 2). In addition to these dominant seabed classes, also long elongated depressions (seabed class "local depression, current scour") occur on the lower north and west slope of the hill (Fig. 2). They are probably the result of enhanced bottom current activity as they coincide well with the depth range in which current indications have been identified on seabed images (Fig. 3). On the lower slope, the high variability in habitats is not so much the result of rugged and complex terrain but of varying abundance of hard substrate. Hard substrate occurs in the form of IRD and also broken off rocks from the hill. Available hard substrate shows high levels of colonisation.

Although geomorphologically distinguishable from the background shelf setting (the maximal spatial extent of the hill is delimited by the "broad slope" class), no sedimentological differences can be identified between the hill foot and the background setting. Both settings are characterised by bioturbated soft sediments. Hard substrate only occurs in the form of IRD. Predicted by the BTM and supported by the seabed images, rock outcrops and escarpments are absent. Small areas of "current scoured depressions" are supported by scoured IRD in the vicinity (Figs. 2 and 3) indicating at least temporarily enhanced bottom currents in this area. In terms of habitat characterisation, the hill foot and the background setting represent a soft bottom habitat typical for the western Weddell Sea shelf (Fillinger et al., 2013; Gutt, 2006). In these areas, hard substrate (IRD) is mostly densely colonised and appears to be the limiting factor for the occurrence of sessile epibenthic organisms. The limited availability of hard substrate is also reflected in generally reduced abundances of sessile epibenthos in these areas. Also the ophiuroids (the only abundant mobile taxon) were less abundant at the hill foot (Fig. 5k).

Benthic habitats and the seabed communities are known to be controlled by a variety of environmental drivers. In this study, we focused primarily on seabed classes and substrate types (Dolan et al., 2008; Wienberg et al., 2008). In addition, we interpret proxies for light conditions (i.e. the depth of the photic zone; e.g. Gómez et al., 1997), disturbance (e.g. iceberg scouring and slope collapse; e.g. Gutt, 2000), bottom currents (e.g. Dorschel et al., 2007) and food availability. Besides characterising the benthic habitats, we have assessed the relationships between environmental and epibenthic biological patterns in order to identify major environmental drivers under the specific setting of the Nachtigaller Hill. The calculations have, however, not provided clear results pointing to one or few dominating drivers. The slightest decrease of the correlation coefficients with changing environmental factor combinations shows that a variety of such combinations can best explain the biological patterns. It is 
thus likely that different factors have different effects at different stations, leading to the weak results of the biostatistical analyses. As expected, among the total of the results with good correlation factors (Table 1), IRD and water depth best explained the biological patterns when using the community data. IRD is a proxy for hard substrate which is especially important for sessile but also for mobile animals. Depth must be considered as a proxy for a variety of relevant ecological factors.

Environmental factors that are not among the best correlations are assumed to have no or only little influence on the epibenthos distribution patterns. Surprisingly, among these factors are some factors that seemed a priori promising as they are either very distinct or obvious at the Nachtigaller Hill and, hence, expected to be ecologically more effective than the same factors in a more homogeneous environment. For example, proxies for enhanced bottom current (ripple marks, current and to some extent erosion) are considered indicators for important ecological factors (Dorschel et al., 2007, 2009). Higher energetic environments should have a significant effect on the epibenthos, especially since bottomnear currents provide an advective food transport for filter feeders (Barry and Dayton, 1988). The environmental factor "ripple marks" is five times among the relevant sediment parameters (Table 2), but other current indicators appear completely irrelevant. Additional proxies for highly dynamic environments are ruggedness (as the result of erosion processes), striation primarily caused by iceberg scouring, small-scale erosive escarpments, and general erosion. Amongst these, striation and erosion represent weak parameters rarely occurring among the best environmental factors, while ruggedness and escarpments turned out to be never really relevant. Likewise, a poor correlation between the smallscale environmental heterogeneity and the benthos has been reported by Cummings et al. (2010) from the shallow Ross Sea at $<25 \mathrm{mwd}$, whilst the sea ice seemed to be an important driver. This has been explained by a high ecological flexibility that allows some species also at greater depths to occur in different habitats with high abundances (Raguá-Gil et al., 2004).

Other sedimentological parameters such as sand, consolidated sediment and soft sediment can affect the benthos distribution patterns. Sand and consolidated sediments are proxies for higher energetic environments, and hence advective food transport, while soft sediments can be indicative for low energetic environments in which finer sediments deposit (McCave et al., 1995) also allowing for the vertical flux and deposition of phytodetritus (Smith et al., 2006). Like IRD, these sedimentological factors might be important for a successful recruitment of early life stages as well as a successful survival and growth for sessile adult organisms. In this study, all these sedimentological factors have only weak influences on the biological data. Surprisingly, the statistical analyses furthermore do not confirm the clear impression from Fig. 5d that the number of phyla is highest at the slope. This pa- rameter is, however, more relevant in the results from analyses of 10 photographs pooled indicating that the large-scale bottom topography is more relevant for the biological patterns than local individual images. A good large-scale correlation between environmental parameters and the megabenthos is also known from the deeper Ross Sea between 270 and $1170 \mathrm{~m}$ wd (Barry et al., 2003). In the Weddell Sea, such a relationship appears to be only weak (Gutt and Starmans, 1998). An obviously steep gradient in advective food supply was observed by Barry and Dayton (1988) at the ice shelf margin in the Ross Sea. Unfortunately, no direct measurements of the food supply to the benthos (e.g. through vertical sedimentation of organic matter from the water column or horizontal advection) are available for this study. However, the enhanced number of animal phyla and greater organism abundances on the hill slope (Fig. 5) probably indicate areas of enhanced levels of benthic food availability. In general, benthos inhabiting the tops and flanks of submarine hills and mounts benefit from hill-specific increased food supply (Genin, 2004; Pitcher et al., 2007; Rogers, 1994; White et al., 2005). Therefore, submarine elevations are home to specific pelagic and benthic communities that differ profoundly in composition, diversity and abundance from those inhabiting the ambient deeper regions (Bowden et al., 2011; Genin et al., 1986; Rogers, 1994).

The seabed classification results (Fig. 2) do not explain any of the biological patterns well. This means that, according to the applied statistical methods, the threedimensional small-scale bottom morphology and potential drivers (e.g. small-scale current regimes) strongly affected by the bottom morphology apparently do not play an important role for the distribution of the epibenthos at the Nachtigaller Hill.

The generally weak correlations between environmental and biological data can have different reasons:

1. Environmental factors, others than those used in this study, are mainly responsible for the biological patterns. Sediment and bottom topography is quite well known in this study. The applied methods also provide valuable information on the generally relevant near-bottom current patterns. However, it cannot be excluded that the very obvious morphological structure of the Nachtigaller Hill acts as an obstacle for the currents on an otherwise levelled shelf and causes current peculiarities such as turbulence and lee situations. Finally, possible superimposed tidal effects are not obvious. At the similarly structured Norsel Bank in the southeast Weddell Sea, a high benthic heterogeneity is attributed to the variability in environmental drivers, including food supply and iceberg disturbance (Raguá-Gil et al., 2004). Furthermore, Gutt and Starmans (1998) and Gutt et al. (1992) show how poorly predictable flux events providing highly variable food supply in space and time 
are reflected in the distribution patterns of epibenthic assemblages and benthic processes.

2. In combination with large-scale effects, small-scale phenomena are of high relevance. The photograph-wise analyses support this interpretation and the number of photographs is generally high enough to decipher smallscale phenomena. However, some of the observed factors (e.g. current ripples, sand, escarpments, striations, current indicators) only occur very rarely (in $<50$ of a total of 1730 photographs). Consequently, the sample size of these specific parameters might be too small to discover statistically significant biota-environment relationships. This confirms earlier findings of a high degree of patchiness in the distribution of Antarctic benthic species, which are driven by a variety of scaledependent processes (Gutt and Starmans, 2003).

3. Computations with 10-binned photographs generally resulted in better correlations. This indicates that environmental factors affect the benthos on a larger $(\sim 100 \mathrm{~m})$ rather than a smaller (single photograph) scale. This explanation does not exclude that local (here single photographs) and possible regional factors (here the entire investigation area) are also relevant. It is plausible that both scales have their specific significance (e.g. bottom currents may primarily act on a larger scale, while small-scale sediment variations and IRD result in local biological patchiness). This scale effect is also known from other studies (e.g. Hogg et al., 2011). In a study from the western tip of the Antarctic Peninsula Lockhart and Jones (2008) identified the presence of different water masses as a large-scale dominant factor for the general distribution patterns of epibenthic assemblages (in the cold Weddell Sea waters sessile suspension feeders and in the warmer Antarctic Circumpolar Current waters mobile echinoderms are dominant). Superimposed, the epibenthic assemblages are highly variable between individual sampling stations (Lockhart and Jones, 2008) probably due to the influence of more local, small-scale environmental factors. Potential large-scale benthic habitats are also classified and characterised within a number of bioregionalisation approaches (Beaman and Harris, 2005; Cummings et al., 2010; Smith et al., 2006). They however do not resolve the coexistence of small-scale, very different distribution patterns of epibenthic assemblages.

4. The investigated environmental factors do not include the main drivers of the biotic patterns at Nachtigaller Hill. Instead, additional biological characteristics and interactions and environmental factors (Gutt, 2000) that are not considered in our study may play an important role in shaping the benthic communities.

\section{Conclusions}

The general geomorphological structure of the hill is well captured, while local features were also represented. Solely derived from bathymetry, the BTM represents a strong tool even for the classification of complex terrains. The geomorphology of the Nachtigaller Hill is characterised by complex and rugged terrain resulting in highly structured, complex heterogeneous habitat distribution. This variability is also represented in species abundances. Hard substrate for sessile epibenthos is abundant at the hill plateau and slope but rare at the hill foot and in the background deep-shelf setting. The distribution patterns of sessile epibenthos are characterised by highly variable small-scale variability rather than broad distribution zones, reflecting the importance of the heterogeneous geomorphology rather than the influence of more continuous environmental parameters such as water depth or water mass. Most likely it reflects the small elevated areas on the hill slope in combination with patchy distributions of hard substrate. In contrast, the less location-dependent mobile fauna showed broader distribution patterns. The statistical correlation between biota and the analysed environmental factors is, however, generally weak.

Acknowledgements. We thank the captain and crew of RV Polarstern as well as the scientific party of cruise ANT XXIX/3 for their excellent support. Special thanks go to Daniel Damaske and José Bedmar for their help during bathymetric data acquisition and to Alexandra Segelken-Voigt and Oliver Piepenburg for their help with the seabed image analyses.

Edited by: W. Kiessling

\section{References}

Absy, J. M., Schröder, M., Muench, R., and Hellmer, H. H.: Early summer thermohaline characteristics and mixing in the western Weddell Sea, Deep-Sea Res. Pt. II, 55, 1117-1131, doi:10.1016/j.dsr2.2007.12.023, 2008.

Arndt, J. E., Schenke, H.-W., Jakobsson, M., Nitsche, F. O., Buys, G., Goleby, B., Rebesco, M., Bohoyo, F., Hong, J., Black, J., Greku, R., Udintsev, G., Barrios, F., Reynoso-Peralta, W., Taisei, M., and Wigley, R.: The International Bathymetric Chart of the Southern Ocean (IBCSO) Version 1.0 - A new bathymetric compilation covering circum-Antarctic waters, Geophys. Res. Lett., 40, 3111-3117, doi:10.1002/grl.50413, 2013.

Barry, J. P. and Dayton, P. K.: Current patterns in McMurdo Sound, Antarctica and their relationship to local biotic communities, Polar Biol., 8, 367-376, 1988.

Barry, J. P., Grebmeier, J. M., Smith, J., and Dunbar, R. B.: Oceanographic Versus Seafloor-Habitat Control of Benthic Megafaunal Communities in the S.W. Ross Sea, Antarctica, in: Biogeochemistry of the Ross Sea, edited by: Ditullio, G. R. and Dunbar, R. B., American Geophysical Union, Washington, DC, 2003. 
Beaman, R. J. and Harris, P. T.: Bioregionalization of the George V Shelf, East Antarctica, Cont. Shelf Res., 25, 1657-1691, doi:10.1016/j.csr.2005.04.013, 2005.

Bergmann, M. and Klages, M.: Increase of litter at the Arctic deepsea observatory HAUSGARTEN, Mar. Pollut. Bull., 64, 27342741, doi:10.1016/j.marpolbul.2012.09.018, 2012.

Bertolin, M. L. and Schloss, I. R. Phytoplankton production after the collapse of the Larsen A Ice Shelf, Antarctica, Polar Biol., 32, 1435-1446, doi:10.1007/s00300-009-0638-x, 2009.

Bowden, D. A., Schiaparelli, S., Clark, M. R., and Rickard, G. J.: A lost world? Archaic crinoid-dominated assemblages on an Antarctic seamount, Deep-Sea Res. Pt. II, 58, 119-127, doi:10.1016/j.dsr2.2010.09.006, 2011.

Burrough, P. A. and McDonell, R. A. Principles of Geographical Information Systems, Oxford University Press, New York, 1998.

Camerlenghi, A., Domack, E. W., Rebesco, M., Gilbert, R., Ishman, S., Leventer, A., Brachfeld, S., and Drake, A.: Glacial morphology and post-glacial contourites in northern Prince Gustav Channel (NWWeddell Sea, Antarctica), Mar. Geophys. Res., 22, 417-443, 2001

Chen, C.-T. and Millero, F. J.: Speed of sound in seawater at high pressures, J. Acoust. Soc. Am., 62, 1129-1135, 1977.

Clarke, A. and Tyler, P. A.: Adult Antarctic Krill Feeding at Abyssal Depths, Curr. Biol., 18, 282-285, doi:10.1016/j.cub.2008.01.059, 2008.

Clarke, K. R. and Gorley, R. N.: PRIMER v6: User manual/tutorial, PRIMER-E Ltd, Plymouth, UK, 2006.

Cummings, V. J., Thrush, S. F., Chiantore, M., Hewitt, J. E., and Cattaneo-Vietti, R.: Macrobenthic communities of the north-western Ross Sea shelf: links to depth, sediment characteristics and latitude, Antarct. Sci., 22, 793-804, doi:10.1017/S0954102010000489, 2010.

Dayton, P. K.: Interdecadal variation in an antarctic sponge and its predators from oceanographic climate shifts, Science, 245, 1484-1486, doi:10.1126/science.245.4925.1484, 1989.

Dayton, P. K.: Polar benthos, in: Polar oceanography, Part B: Chemistry, biology, and geology, edited by: Smith, W. O., Academic Press, London, 631-685, 1990.

Dayton, P. K., Kim, S. J., Shannon C. , Oliver, J. S., Hammerstrom, K., Fisher, J. L., O’Connor, K., Barber, J. S., Robilliard, G. A., Barry, J., Thurber, A. R., and Conlan, K.: Recruitment, Growth and Mortality of an Antarctic Hexactinellid Sponge, Anoxycalyx joubini, PLoS ONE, 8, e56939, doi:10.1371/journal.pone.0056939, 2013.

Dolan, M. F. J., Grehan, A. J., Guinan, J. C., and Brown, C.: Modelling the local distribution of cold-water corals in relation to bathymetric variables: Adding spatial context to deep-sea video data, Deep-Sea Res. Pt. I, 55, 1564-1579, 2008.

Dorschel, B., Hebbeln, D., Foubert, A. T. G., White, M., and Wheeler, A. J.: Hydrodynamics and cold-water coral facies distribution related to recent sedimentary processes at Galway Mound west of Ireland, Mar. Geol., 244, 184-195, doi:10.1016/j.margeo.2007.06.010, 2007.

Dorschel, B., Wheeler, A. J., Huvenne, V. A. I., and de Haas, H.: Cold-water coral mounds in an erosive environmental setting: TOBI side-scan sonar data and ROV video footage from the northwest Porcupine Bank, NE Atlantic, Mar. Geol., 264, 218 229, 2009
Erdey-Heydorn, M. D.: An ArcGIS Seabed Characterization Toolbox Developed for Investigating Benthic Habitats, Mar. Geodes. 31, 318-358, doi:10.1080/01490410802466819, 2008.

Fillinger, L., Janussen, D., Lundälv, T., and Richter, C.: Rapid Glass Sponge Expansion after Climate-Induced Antarctic Ice Shelf Collapse, Curr. Biol., 23, 1330-1334, doi:10.1016/j.cub.2013.05.051, 2013.

Fischer, G. and Wiencke, C.: Stable carbon isotope composition, depth distribution and fate of macroalgae from the Antarctic Peninsula region, Polar Biol., 12, 341-348, 1992.

Genin, A.: Bio-physical coupling in the formation of zooplankton and fish aggregations over abrupt topographies, J. Mar. Syst., 50, 3-20, doi:10.1016/j.jmarsys.2003.10.008, 2004.

Genin, A., Dayton, P. K., Lonsdale, P. F., and Spiess, F. N. Corals on seamount peaks provide evidence of current acceleration over deep-sea topography, Nature, 322, 59-61, doi:10.1038/322059a0, 1986.

Gerdes, D., Klages, M., Arntz, W. E., Herman, R. L., Galéron, J., and Hain, S.: Quantitative investigations on macrobenthos communities of the southeastern Weddell Sea shelf based on multibox corer samples, Polar Biol., 12, 291-301, doi:10.1007/BF00238272, 1992.

Gómez, I., Weykam, G., Klöser, H., and Wiencke, C.: Photosynthetic light requirements, metabolic carbon balance and zonation of sublittoral macroalgae from King George Island (Antarctica), Mar. Ecol.-Prog. Ser., 148, 281-293, 1997.

Grange, L. J. and Smith, C. R.: Megafaunal Communities in Rapidly Warming Fjords along the West Antarctic Peninsula: Hotspots of Abundance and Beta Diversity, PLoS ONE, 8, e77917, doi:10.1371/journal.pone.0077917, 2013.

Guinan, J., Grehan, A. J., Dolan, M. F. J., and Brown, C.: Quantifying relationships between video observations of cold-water coral cover and seafloor features in Rockall Trough, west of Ireland. Mar. Ecol.-Prog. Ser., 375, 125-138, 2009.

Guo, Y., Davies, P. A., Cavalletti, A., and Jacobs, P.: Topography and stratification effects on shelf edge flows, Dynam. Atmos. Ocean, 31, 73-116, 2000.

Gutt, J.: Some "driving forces" structuring communities of the sublittoral Antarctic macrobenthos, Antarct. Sci., 12, 297-313, doi:10.1017/S0954102000000365, 2000.

Gutt, J.: Coexistence of macro-zoobenthic species on the Antarctic shelf: An attempt to link ecological theory and results. DeepSea Res. Pt. II, 53, 1009-1028, doi:10.1016/j.dsr2.2006.02.012, 2006.

Gutt, J.: Antarctic macro-zoobenthic communities: a review and an ecological classification, Antarct. Sci., 19, 165-182, doi:10.1017/S0954102007000247, 2007.

Gutt, J.: The Expedition of the Research Vessel "Polarstern" to the Antarctic in 2013 (ANT-XXIX/3), Berichte zur Polarforschung und Meeresforschung, p. 150, 2013.

Gutt, J. and Siegel, V.: Benthopelagic aggregations of krill (Euphausia superba) on the deeper shelf of the Weddell Sea (Antarctic), Deep-Sea Res. Pt. I, 41, 169-178, doi:10.1016/09670637(94)90031-0, 1994.

Gutt, J. and Starmans, A.: Structure and biodiversity of megabenthos in the Weddell and Lazarev Seas (Antarctica): ecological role of physical parameters and biological interactions, Polar Biol., 20, 229-247, 1998. 
Gutt, J. and Starmans, A.: Patchiness of the megabenthos at small scales: ecological conclusions by examples from polar shelves, Polar Biol., 26, 276-278, 2003.

Gutt, J., Gerdes, D., and Klages, M.: Seasonality and spatial variability in the reproduction of two Antarctic holothurians (Echinodermata), Polar Biol., 11, 533-544, 1992.

Gutt, J., Barratt, I., Domack, E.W., d'Udekem d'Acoz, C., Dimmler, W., Grémare, A., Heilmayer, O., Isla, E., Janussen, D., Jorgensen, E., Kock, K.-H., Lehnert, L. S., López-Gonzáles, P., Langner, S., Linse, K., Manjón-Cabeza, M. E., Meißner, M., Montiel, A., Raes, M., Robert, H., Rose, A., Schepisi, E. S., Saucède, T., Scheidat, M., Schenke, H.-W., Seiler, J., and Smith, C. R.: Biodiversity change after climate-induced iceshelf collapse in the Antarctic, Deep-Sea Res. Pt. II, 58, 74-83, doi:10.1016/j.dsr2.2010.05.024, 2011.

Gutt, J., Zurell, D., J., B. T., Cheung, W., Clark, M. S., Convey, P., Danis, B., David, B., De Broyer, C., di Prisco, G., Griffiths, H., Laffont, R., Peck, L. S., Pierrat, B., Riddle, M. J., Saucède, T., Turner, J., Verde, C., Wang, Z., and Grimm, V.: Correlative and dynamic species distribution modelling for ecological predictions in the Antarctic: a cross-disciplinary concept, Polar Res., 31, 11091, doi:10.3402/polar.v31i0.11091, 2012.

Gutt, J., Barnes, D. K. A., Lockhart, S. J., and van de Putte, A.: Antarctic macrobenthic communities: A compilation of circumpolar information, Nat. Conserv., 4, 1-13, doi:10.3897/natureconservation.4.4499, 2013a.

Gutt, J., Griffiths, H. J., and Jones, C. D.: Circumpolar overview and spatial heterogeneity of Antarctic macrobenthic communities, Mar. Biodivers., 43, 481-487, doi:10.1007/s12526-013-0152-9, 2013b.

Hogg, O. T., Barnes, D. K. A., and Griffiths, H. J.: Highly Diverse, Poorly Studied and Uniquely Threatened by Climate Change: An Assessment of Marine Biodiversity on South Georgia's Continental Shelf, PLoS ONE, 6, e19795, doi:10.1371/journal.pone.0019795, 2011.

Jakobsson, M., Cherkis, N., Woodward, J., Macnab, R., and Coakley, B.: New grid of Arctic bathymetry aids scientists and mapmakers, EOS Trans., 81, 89-96, doi:10.1029/00EO00059, 2000.

Jakobsson, M., Macnab, R., Mayer, L. A., Anderson, R. F., Edwards, M., Hatzky, J., Schenke, H.-W., and Johnson, P.: An improved bathymetric portrayal of the Arctic Ocean: Implications for ocean modeling and geological, geophysical and oceanographic analyses, Geophys. Res. Lett., 35, L07602, doi:10.1029/2008GL033520, 2008.

Jakobsson, M., Mayer, L. A., Coakley, B., Dowdeswell, J. A., Forbes, S., Fridman, B., Hodnesdal, H., Noormets, R., Pedersen, R., Rebesco, M., Schenke, H.-W., Zarayskaya, Y., Accettella, D., Armstrong, A., Anderson, R. M., Bienhoff, P., Camerlenghi, A., Church, I., Edwards, M., Gardner, J. V., Hall, J. K., Hell, B., Hestvik, O. B., Kristoffersen, Y., Marcussen, C., Mohammad, R., Mosher, D., Nghiem, S. V., Pedrosa, M. T., Travaglini, P. G., and Weatherall, P.: The International Bathymetric Chart of the Arctic Ocean (IBCAO) Version 3.0, Geophys. Res. Lett., 39, L12609, doi:10.1029/2012GL052219, 2012.

Lavaleye, M. S. S., Thatje, S., Duineveld, G., and Arntz, W. E.: Pelagic larvae and juveniles of benthic invertebrates in the nearbottom environment, Berichte zur Polarforschung, 503, 31-35, 2005.
Lockhart, S. J. and Jones, C. D.: Biogeographic patterns of benthic invertebrate megafauna on shelf areas within the Southern Ocean Atlantic sector, CCAMLR Science, 15, 167-192, 2008.

Lundblad, E., Wright, D. J., Miller, J., Larkin, E. M., Rinehart, R., Naar, D. F., Donahue, B. T., Anderson, S. M., and Battista, T.: A benthic terrain classification scheme for American Samoa, Mar. Geodes., 29, 89-111, doi:10.1080/01490410600738021, 2006.

McCave, I. N., Manighetti, B., and Robinson, S. G.: Sortable silt and fine sediments size/composition slicing: Parameters for paleocurrent speed and palaeoceanography, Paleoceanography, 10, 593-610, 1995.

Orsi, A. H., Nowlin Jr., W. D., and Whitworth III, T.: On the circulation and stratification of the Weddell Gyre, Deep-Sea Res. Pt. I, 40, 169-203, 1993.

Peck, L. S., Barnes, D. K. A., Cook, A. J., Fleming, A. H., and Clarke, A.: Negative feedback in the cold: ice retreat produces new carbon sinks in Antarctica. Glob. Change Biol., 16, 26142623, doi:10.1111/j.1365-2486.2009.02071.x, 2010.

Piepenburg, D. and Müller, B.: Distribution of epibenthic communities on the Great Meteor Seamount (North-east Atlantic) mirrors pelagic processes, Arch. Fish. Mar. Res., 51, 55-70, 2004.

Piepenburg, D., Schmid, M. K., and Gerdes, D.: The benthos off King George Island (South Shetland Islands, Antarctica): further evidence for a lack of a latitudinal biomass cline in the Southern Ocean, Polar Biol., 25, 146-158, doi:10.1007/s003000100322, 2002.

Pitcher, T. J., Morato, T., Hart, P. J. B., Clark, M. R., Haggan, N., and Santos, R. S.: Seamounts: Ecology, Fisheries \& Conservation, Blackwell Pub Professional, 2007.

Post, A. L., Beaman, R. J., O’Brien, P. E., Eléaume, M., and Riddle, M. J.: Community structure and benthic habitats across the George V Shelf, East Antarctica: Trends through space and time, Deep-Sea Res. Pt. II, 58, 105-118, doi:10.1016/j.dsr2.2010.05.020, 2011.

Raguá-Gil, J. M., Gutt, J., Clarke, A., and Arntz, W. E.: Antarctic shallow-water mega-epibenthos: shaped by circumpolar dispersion or local conditions?, Mar. Biol., 144, 829-839, doi:10.1007/s00227-003-1269-3, 2004.

Rogers, A. D.: The biology of seamounts, Adv. Mar. Biol., 30, 305350, doi:10.1016/S0065-2881(08)60065-6, 1994.

Sañe, E., Isla, E., Bárcena, M. Á., and DeMaster, D. J.: A Shift in the Biogenic Silica of Sediment in the Larsen B Continental Shelf, Off the Eastern Antarctic Peninsula, Resulting from Climate Change, PLoS ONE, 8, e52632, doi:10.1371/journal.pone.0052632, 2013.

Sangrà, P., García-Muñoz, C., García, C. M., Marrero-Díaz, Á., Sobrino, C., Mouriño-Carballido, B., Aguiar-González, B., Henríquez-Pastene, C., Rodríguez-Santana, Á., Lubián, L. M., Hernández-Arencibia, M., Hernández-León, S., Vázquez, E., and Estrada-Allis, S. N.: Coupling between upper ocean layer variability and size-fractionated phytoplankton in a nonnutrient-limited environment, Mar. Ecol.-Prog. Ser., 499, 35-46, doi:10.3354/meps10668, 2014.

Schmidt, K., Atkinson, A., Steigenberger, S., Fielding, S., Lindsay, M. C. M., Pond, D. W., Tarling, G. A., Klevjer, T. A., Allen, C. S., Nicol, S., Achterbergb, E. P.: Seabed foraging by Antarctic krill: Implications for stock assessment, bentho-pelagic coupling, and the vertical transfer of iron, Limnol. Oceanogr., 56, 1411-1428, doi:10.4319/lo.2011.56.4.1411, 2011. 
Schröder, M., Hellmer, H. H., and Absy, J. M.: On the near-bottom variability in the northwestern Weddell Sea, Deep-Sea Res. Pt. II, 49, 4767-4790, doi:10.1016/S0967-0645(02)00158-3, 2002.

Smith, C. R., Mincks, S., and DeMaster, D. J.: A synthesis of bentho-pelagic coupling on the Antarctic shelf: Food banks, ecosystem inertia and global climate change, Deep-Sea Res. Pt. II, 53, 875-894, doi:10.1016/j.dsr2.2006.02.001, 2006.

Starmans, A., Gutt, J., and Arntz, W. E.: Mega-epibenthic communities in Arctic and Antarctic shelf areas, Mar. Biol., 135, 269 280, doi:10.1007/s002270050624, 1999.

Sugden, D. E.: Arctic and Antarctic: A Modern Geographical Synthesis, Basil Blackwell, Oxford, 1982.

Sumida, P. Y. G., Bernardino, A. F., Stedall, V. P., Glover, A. G., and Smith, C. R.: Temporal changes in benthic megafaunal abundance and composition across the West Antarctic Peninsula shelf: Results from video surveys, Deep-Sea Res. Pt. II, 55, 2465-2477, doi:10.1016/j.dsr2.2008.06.006, 2008.

Thatje, S., Hillenbrand, C.-D., and Larter, R. D.: On the origin of Antarctic marine benthic community structure, Trends Ecol. Evol., 20, 531-540, doi:10.1016/j.tree.2005.07.010, 2005.

Weiss, A. D.: Topographic Position and Landforms Analysis, 2001.

White, M., Mohn, C., de Stigter, H. C., and Mottram, G.: Deepwater coral development as a function of hydrodynamics and surface productivity around the submarine banks of the Rockall Trough, NE Atlantic, in: Cold-water Corals and Ecosystems, edited by: Freiwald, A. and Roberts, J. M., Springer, Berlin, Heidelberg, New York, 503-514, 2005.

Wienberg, C., Beuck, L., Heidkamp, S., Hebbeln, D., Freiwald, A., Pfannkuche, O., and Monteys, F. X.: Franken Mound: facies and biocoenoses on a newly-discovered "carbonate mound" on the western Rockall Bank, NE Atlantic, Facies, 54, 1-24, 2008.
Wienberg, C., Wintersteller, P., Beuck, L., and Hebbeln, D.: Coral Patch seamount (NE Atlantic) - a sedimentological and megafaunal reconnaissance based on video and hydroacoustic surveys, Biogeosciences, 10, 3421-3443, doi:10.5194/bg-10-3421-2013, 2013.

Wiencke, C., Clayton, M. N., Gómez, I., Iken, K., Lüder, U. H., Amsler, C. D., Karsten, U., Hanelt, D., Bischof, K., and Dunton, K.: Life strategy, ecophysiology and ecology of seaweeds in polar waters, Rev. Environ. Sci. Biotechnol., 6, 95-126, doi:10.1007/s11157-006-9106-z, 2007.

Williams, I. M. and Leach, J. H. J.: The relationship between depth, substrate and ecology: a drop video study from the southeastern Australian coast, Oceanol. Acta, 22, 651-662, 1999.

Wilson, M. F. J., O'Connell, B., Brown, C., Guinan, J. C., and Grehan, A. J.: Multiscale Terrain Analysis of Multibeam Bathymetry Data for Habitat Mapping on the Continental Slope, Mar. Geodes., 30, 3-35, 2007.

Wood, J.: LandSerf 2.3.1, 2009a.

Wood, J.: The LandSerf Manual Version 1.0, 3rd December 2009 for LandSerf 2.3.1, p. 213, 2009b.

Wright, D. J., Lundblad, E. R., Larkin, E. M., Rinehart, R. W., Murphy, J., Cary-Kothera, L., and Draganov, K.: ArcGIS Benthic Terrain Modeler [a collection of tools used with bathymetric data sets to examine the deepwater benthic environment], Oregon State University, Davey Jones' Locker Seafloor Mapping/Marine GIS Laboratory and NOAA Coastal Services Center, 2005.

Wulff, A., Iken, K., Quartino, M. L., Al-Handal, A., Wiencke, C., and Clayton, M. N.: Biodiversity, biogeography and zonation of marine benthic micro- and macroalgae in the Arctic and Antarctic, Bot. Mar., 52, 491-507, doi:10.1515/BOT.2009.072, 2009. 